\title{
Employees as influencers: measuring employee brand equity in a social media age
}

\author{
Donna Smith, Fenna Facobson and Fanice L. Rudkowski \\ Ted Rogers School of Management, Ryerson University, Toronto, Canada
}

\begin{abstract}
Purpose - The practice of frontline employees articulating their brand voice and posting work-related content on social media has emerged; however, employee brand equity (EBE) research has yet to be linked to employees' social media activity. This paper aims to take a methods-based approach to better understand employees' roles as influencers. As such, its objective is to operationalize and apply the three EBE dimensions brand consistent behavior, brand endorsement and brand allegiance - using Instagram data.

Design/methodology/approach - This qualitative research uses a case study of employee influencers at SoulCycle, a leading North American fitness company and examines 100 Instagram images and 100 captions from these influential employees to assess the three EBE dimensions.

Findings - Brand consistent behavior (what employees do) was the most important EBE dimension indicating that employees' social media activities align with their employer's values. Brand allegiance (what employees intend to do in the future) whereby employees self-identify with their employer on social media, followed. Brand endorsement (what employees say) was the least influential of the three EBE dimensions, which may indicate a higher level of perceived authenticity from a consumer perspective.

Originality/value - This research makes three contributions. First, it presents a novel measure of EBE using public Instagram data. Second, it represents a unique expansion and an evolution of King et al.'s (2012) model. Third, it considers employees' work-related content on social media to understand employees' role as influencers and their co-creation of EBE, which is currently an under-represented perspective in the internal branding literature.
\end{abstract}

Keywords Instagram, Employee voice, Internal branding, Employee brand equity, Employee influencers, Employee social media

Paper type Research paper

\section{Introduction}

Marketing scholars and practitioners increasingly acknowledge the important role that employees play in brand value co-creation (Merrilees et al., 2017; Glanfield et al., 2018; Chou et al., 2018) and the internal branding process (Du Preez et al., 2017; Boukis and Christodoulides, 2020). In the eyes of the consumer, employees can embody and personify the corporate brand. This is especially true for service-based corporate brands, where employees interact directly with consumers and are responsible for delivering positive and authentic brand experiences. While frontline employee behavior and service delivery can be powerful tools in holistic branding strategy, corporate brands have traditionally focused on a consumer-targeted context (Brexendorf and Kernstock, 2007) whereby consumers' in-role (i.e. participation) and extra-role (i.e. voluntary citizenship) behaviors contribute to the co-creation of brand value (Yi and Gong, 2013; Chou et al., 2018). As such, a tripartite model of brand management that includes consumer-based brand equity, financial-based brand equity, and importantly, employee brand equity should be considered (King et al., 2012). Employee brand equity (EBE) is defined by King and Grace (2009) as " [...] the differential effect that brand knowledge has on an employee's

The current issue and full text archive of this journal is available on Emerald Insight at: https://www.emerald.com/insight/1061-0421.htm

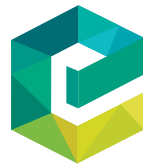

Journal of Product \& Brand Management 30/6 (2021) 834-853

Emerald Publishing Limited [ISSN 1061-0421] [DOI 10.1108/JPBM-03-2020-2821] response to their work environment" (p. 142). The concept has evolved and is conceptualized as three dimensions:

1 brand consistent behavior: behavior that is aligned with the brand values of the organization;

2 brand endorsement: positive external communication about the brand; and

\footnotetext{
(C) Donna Smith, Jenna Jacobson and Janice L. Rudkowski. Published by Emerald Publishing Limited. This article is published under the Creative Commons Attribution (CC BY 4.0) licence. Anyone may reproduce, distribute, translate and create derivative works of this article (for both commercial and non-commercial purposes), subject to full attribution to the original publication and authors. The full terms of this licence may be seen at http://creativecommons.org/licences/by/4.0/legalcode
}

This paper forms part of a special section "Internal Branding: in Search of a New Paradigm", guest edited by Holger J. Schmidt, Nicholas J. Ind and Oriol Iglesias.

Funding: The research was supported by Mitacs Globalink Program, and a SSHRC Explore Grant (PI: Jenna Jacobson).

Disclosure statement: No potential conflict of interest was reported by the authors.

Eratum: It has come to the attention of the publisher that the article "Employees as influencers: measuring employee brand equity in a social media age" published in fournal of Product $\&$ Brand Management, Vol. aheadof-print No. ahead-of-print, included incorrect bibliographic information. This error was introduced in the editorial process and has now been corrected in the online version. The publisher apologises for this error.

Received 30 March 2020

Revised 6 August 2020

20 November 2020

Accepted 15 December 2020 
3 brand allegiance: employees' future intention to remain with their organization (King et al., 2012).

As organizations build their brands, the role of social media in the customer journey and brand value co-creation is becoming increasingly important. Brand-to-customer, customer-tocustomer, customer-to-brand, employee-to-employee, employee-to-customer, and employee-to-brand touchpoints via social media have disrupted and blurred the traditional prepurchase, purchase, and post-purchase stages of the customer journey (Lemon and Verhoef, 2016), as well as the internal and external branding activities and strategies. Merrilees et al. (2017) argue "[...] just as customers co-create by offering new ideas and suggestions to firms, so too do staff” (p. 250). Organizations heavily invest in social media to showcase their brand and build relationships based on the brand (Hambrick and Kang, 2015). Indeed, according to an industry survey, $50 \%$ of participants in the USA follow their favorite brands on social media (Statista, 2018).

At the same time, employees are becoming increasingly empowered to voice their opinions on employer review sites and post work-related content on social media such as Instagram or TikTok. This has given rise to employee influencers, which manifests as employees influencing consumers' perceptions, employees influencing other employees' perceptions of the brand, employees' co-creating value (Roncha and Radclyffe-Thomas, 2016) and employees championing the brand (Morhart et al., 2009). Internal stakeholders (i.e. employees) are influencing external stakeholders (i.e. consumers) via external communication instruments (i.e. social media). Instagram has over 1 billion monthly active users making it a particularly compelling brandbuilding social media platform for corporate brands (Clement, 2020), who face increasing competition and pressure to innovate and respond appropriately to changing consumer needs and behaviors. Thus, this research is situated at the intersection of three contemporary trends: employees' influence within the internal branding and brand value co-creation process; organizations' use of social media to build their brands; and employees' roles as influencers whereby they voice their opinions, post-work-related content on social media, express their perceptions of their employer's brand and influence consumers via social media.

This research seeks to operationalize and apply the three dimensions of EBE using Instagram data and is important from two perspectives. First, the traditional view of how to develop and grow branded service encounters and co-create value is expanding. In high touch service organizations, there is often a focus on rigorous recruiting, training and development, and marketing the brand to employees (Erkmen, 2018). Second, another perspective advocates the addition of empowering employees "[ . . . ] a degree of personal latitude to bring the brand to live authentically in their own manner during service encounters" (Sirianni et al., 2013, p. 120). Employees' use of social media related to the workplace exemplifies this direction. It is important to study the diverse, contemporary contexts in which EBE manifests. Since the concept's inception, existing empirically tested scales for EBE typically rely on data collected from employees through surveys or interviews (King et al., 2012). Academic research on employee brand equity has not kept pace with employee behavior, as there is yet, to the authors' knowledge, a study of employee brand equity linked to employees' social media activity where employees express their perceptions of their employer's brand by posting work-related content to an external audience.

This research specifically addresses a gap in the internal branding literature identified through the work of Saleem and Iglesias (2016) and King (2017). As such, the objective of this research is to operationalize and apply three dimensions of EBE - brand consistent behavior, brand endorsement, and brand allegiance - in a social media context, using Instagram data. A methods-based approach is used to understand employees' roles as influencers and cocreators of brand value and develop a novel measure of employee brand equity using public social media data.

The paper is organized as follows. The literature review examines the conceptual foundations of internal branding (Section 2.1) and employee voice and employee influencers in the context of social media (Section 2.2). EBE is outlined as the theoretical framework underpinning this research (Section 3). The research method is then described, including case selection in the fitness and wellness industry, sampling strategies, and justification for the newly developed measures used for each of the three dimensions of EBE - including brand consistent behavior, brand endorsement, and brand allegiance (Section 4). The findings are analyzed for each of the three dimensions (Section 5), they are discussed (Section 6), and the paper concludes with theoretical contributions, managerial implications, limitations, and future research (Section 7).

\section{Literature review}

\subsection{Internal branding}

Brands are an organization's most valuable intangible assets (Keller and Lehmann, 2006). Today, brands are no longer viewed as static and lifeless products or services; rather, they are dynamic, experiential, and multi-faceted entities co-created by a variety of stakeholders, including consumers and employees (Veloutsou and Guzman, 2017). By developing a strong company brand, and one that consistently delivers on its brand promise, an organization garners both competitive advantages and financial benefits (King and Grace, 2009). As a result, organizations are motivated to invest in two types of branding strategies and activities: external brand management (i.e. consumer-focused) and internal brand management (i.e. employee-focused).

Traditionally, brands have been managed via external branding practices that take an outward focus and rely on consumers (e.g. external stakeholders), their perceptions, and insights to drive brand growth opportunities. France et al. (2015) define customer co-creation behaviors as "customer-led interactions between the customer and the brand" (p. 852). Internal branding practices, however, use traditional brand management tools to motivate employees (e.g. internal stakeholders) to achieve an organization's goals and objectives (Rafiq and Ahmed, 2000). In the context of better understanding the employee branding process, internal branding is described by Miles and Mangold (2004) as the process whereby "[...] employees internalize the desired brand image and are motivated to project the image to customers and other organizational constituents" (p. 68). King et al. (2012) describe internal branding as an essential component of brand management whereby employees deliver the brand promise organizations have communicated to their consumers. Further, internal branding 
enables positive employee behaviors and employees' ability to operationalize the brand (King et al., 2012). While brand co-creation is typically associated with the customer-brand relationship (France et al., 2018), brands can also be co-created by employees. Indeed, Merrilees et al. (2017), in their study of staff-led value co-creation, found that employees who are engaged, empowered, and have values that are congruent with their organization are motivated toward staff-led service innovation such as proactively helping clients, recruiting new clients, and prospective employees. From an internal branding perspective, employees play an important role in influencing how external stakeholders view the brand (Wangenheim et al., 2007), delivering the brand promise (Burmann and Zeplin, 2005; Punjaisri and Wilson, 2011), and co-creating the brand (Payne et al., 2009; Merrilees et al., 2017).

External branding and its contribution to consumer brand equity are well documented in the literature (Aaker, 1992; Keller, 1993; Yoo and Donthu, 2001; Gil-Saura et al., 2013; Anselmsson et al., 2017). Internal branding, relative to the extensive literature on external branding, studied in the context of EBE is limited, however, it continues to develop (Miles and Mangold, 2004; King and Grace, 2009; Baumgarth and Schmidt, 2010; King et al., 2012; Gelb and Deva, 2014; Kashive and Tandon Khanna, 2017). While consumer brand equity literature is rooted in the cognitive psychology theory of associative networks, EBE literature is rooted in internal branding. Research has shown internal branding impacts employee satisfaction, which, in turn, impacts customer satisfaction (Thomson et al., 1999). Mikic Little and Dean (2006) also link employee commitment to brand performance, as well as financial and reputational benefits.

There is a lack of scholarly consensus as to whether external or internal branding strategies and activities should be emphasized, whether both strategies should be given equal weight or whether building brand equity starts with internal or external branding. Harris (2007) argues that internal branding should be prioritized over external branding, thus emphasizing the employee over the consumer in an organization's brandbuilding efforts. Yet, other scholars have argued the consumer and employee hold equal importance in overall brand management practices (de Chernatony and Dall'Olmo Riley, 1999). Similarly, the value co-creation literature is predominantly consumer-centric (McColl-Kennedy et al., 2012), with little attention paid to the role of alternate contributors (Gummesson, 2008) such as employee-led brand value co-creation (Merrilees et al., 2017). King and Grace (2009) believe that if organizations make the brand meaningful and relevant to employees, employees will exhibit positive brand behaviors, which, in turn, manifests in brand equity. Finally, Poulis and Wisker (2016) argue that the process of building an organization's brand equity starts with internal branding.

In practice, the marketing department typically oversees external branding efforts while the human resources department manages the internal branding strategies and activities within an organization. Even though management of the internal and external brand may be viewed as separate responsibilities within an organization, the lines between them have become increasingly blurred. Just as consumers form strong relationships with brands (Fournier, 1998), so do employees. The relationship an employee has with its organizational brand manifests as brand commitment (King and Grace, 2009), brand engagement (Kumar and Pansari, 2014), brand identification (Hughes and Ahearne, 2010), and brand advocacy (Badrinarayanan and Laverie, 2011). Gelb and Deva (2014) identify that employees contribute to brand equity as brand differentiators and brand ambassadors and conclude that brand equity can be leveraged as a recruiting tool. Raj Devasagayam et al. (2010) also mention the importance of internal brand communities, comprising employees who support and develop the delivery of a brand identity. These insights, of interest to practitioners and scholars alike, should be considered when conceptualizing EBE.

\subsection{Employee voice, employee influencers and social media}

Employees express their opinions, positive and negative, about organizational phenomena and this is referred to as employee voice (Miles and Muuka, 2011). Prior to the adoption of social media, employee voice was expressed through informal interpersonal communication and through internal formal systems. The former mitigates risk to the employee when dissent is present (Kassing, 2002). It is in the employer's best interest to guide and manage employee voice and to provide an internal system that embraces employee dissent without undue risk to the employee (Miles and Mangold, 2004). Employers may want to try to control employee voice to ensure it is aligned with the brand's positioning and values; however, this is not a realistic objective in today's highly connected world. Rather, employees feel empowered (Gill-Simmen et al., 2018) and this has facilitated the rise of co-created brands (Ind et al., 2013; Saleem and Iglesias, 2016; Homburg et al., 2017) whereby consumers and employees, along with the firms themselves, influence the brand value co-creation process.

The use of employment-related social media platforms such as LinkedIn and Glassdoor.com provides an arena for employees to discuss, review, and rank employers. The external expression of employee voice on social media may influence prospective employees and the general public's perception of the corporate brand (Pitt et al., 2019). A more pervasive form of expressing employee voice is on social media platforms that are not specifically workplace-oriented (Holland et al., 2016) such as Facebook, Twitter, and Instagram. While the literature on employee voice originally focused on the impact of employees' negative opinions of the workplace in an internal organizational context, the research has evolved to include an examination of how organizations can guide, stimulate, and engage employees in the use of social media to elicit authenticity of employee voice without excessive organizational interference (Martin et al., 2015).

Individuals on social media who are perceived to be experts, and who build up a follower base while promoting brands, are referred to as opinion leaders or influencers (Erz et al., 2018). The concept of opinion leaders was first introduced by Katz and Lazarsfeld (1955) in the study of a communication flow model and has since been extensively applied within the marketing literature (Watts and Dodds, 2007; Trusov et al., 2010; Iyengar et al., 2011). Micro-influencers have high credibility in a specific area of expertise, which enables them to garner high levels of trust and engagement with their followers 
(De Veirman et al., 2017; Su et al., 2018). The practice of influencer marketing involves corporations financially compensating social media influencers (which includes microinfluencers) to deliver marketing messages (Singh et al., 2020) on their behalf to enhance consumers' perceptions about the brand and subsequent purchase intentions (Lu et al., 2014). From a brand value co-creation perspective, selective employees with an influential social media presence may be considered opinion leaders by their peers and/or take on the role of "employee influencer" to promote and/or voice their opinions (negative or positive) about their workplace and their employer's corporate brand. Unlike social media influencers, employee influencers are typically not financially compensated by their organizations to deliver marketing messages. Promoting their organizations through social media is generally considered extra-role or organizational citizenship behaviors (Organ, 1988), that is, employee behavior that is discretionary (Paine and Organ, 2000) conducted outside the organization and falls outside their job descriptions (Islam and Tariq, 2018).

\section{Theoretical framework: employee brand equity}

Brand equity can be measured from a consumer, financial or employee perspective; regardless of the stakeholder perspective, it is a critical performance indicator of a brand's success (Duncan et al., 2019). King and Grace's (2009) pioneering work on EBE is based on social identity theory (Tajfel and Turner, 1986) and has evolved throughout the past decade (King and Grace, 2010; King et al., 2012; King, 2017). $\mathrm{EBE}$ is experiencing a revival within the internal branding literature (Poulis and Wisker, 2016; Kashive and Tandon Khanna, 2017; Altaf and Shahzad, 2018; Erkmen, 2018; Boukis and Christodoulides, 2020). EBE embraces a critical, yet often overlooked, internal stakeholder perspective (e.g. the employee). Using the lens of social brand identification, employees are able to gain a sense of belonging, as well as, provide knowledge about their company's brand promise (Miles and Mangold, 2014), their roles (Tosti and Stotz, 2001), and the value of their external communications as part of the internal branding process (Erkmen, 2018).

$\mathrm{EBE}$, the theoretical foundation for this study, is defined as "[...] the differential effect that brand knowledge has on an employee's response to internal brand management" (King et al., 2012, p. 269). This definition stems from Keller's (1993) definition of consumer-based brand equity (CBBE), defined as "the differential effect of brand knowledge on consumer response to the marketing of the brand" (p. 1). In contrast to CBBE, which measures consumers' perceptions of the brand, $\mathrm{EBE}$ is measured from employees' (i.e. internal stakeholders) perspectives. Thus, this study uses employees' Instagram posts (i.e. a communication channel that enables employees to deliver messages about their organization, according to their own perceptions, to external stakeholders) to assess EBE (i.e. indirect effect), using both behavioral (i.e. what they say and do) and cognitive aspects (i.e. what they intend to do in the future) of brand equity from an employee's perspective. This study adopts King et al.'s (2012) identification based EBE and conceptualizes it as three dimensions: brand consistent behavior; brand endorsement; and brand allegiance.
In broad terms, brand consistent behavior measures what employees $d o$, brand endorsement measures what employees say, and brand allegiance measures what employees intend to do in the future (King et al., 2012).

Brand consistent behavior is defined as employee behavior that is not prescribed (Burmann et al., 2009), is beyond the call of duty, and consistent with the brand values of the organization (King et al., 2012); it does not refer to the explicit expectations of an employee as outlined in their job description (i.e. roles and responsibilities). It is analogous to Burmann and Zeplin's (2005) brand citizenship behavior and is a pivotal driver of successful internal branding - a component of employee engagement and a key dimension of EBE (Burmann et al., 2009). If employees post content on social media that aligns with the brand values of their organization, the employees have internalized the brand's attributes (Poulis and Wisker, 2016) and would arguably have a positive influence on the brand to individuals reading the post. Employees' social media behavior cannot be controlled by the organization; however, it does impact the company's overall success. Therefore, organizations hope their employees' social media posts are aligned positively with their brand values. For the purposes of this study, an employee who demonstrates high brand consistent behavior can be described as living the values of the brand via their personal and professional Instagram posts.

Brand endorsement is defined as " [...] the extent to which an employee is willing to say positive things about the organization and to readily recommend the organization to others" (King et al., 2012, p. 274). Similar to how customers endorse products or companies through online review sites, employees may also post social media content that either directly or indirectly endorses their employer. When employees are endorsing the organization's brand to external stakeholders, they are positively influencing their organization's brand equity due to their intrinsic or extrinsic motivation to do so (Poulis and Wisker, 2016). Brand endorsement includes both verbal employee behaviors (e.g. mentioning the organization in the caption) and non-verbal employee behaviors (e.g. wearing the organization's branded merchandise) (King et al., 2012; Henkel et al., 2007). The verbal employee behaviors capture what employees say, whereas the non-verbal employee behaviors capture what employees do. Brand endorsement on social media may be a new form of product placement. Product placement is a promotional tool used by brands whereby a product is stealthily incorporated into another media; traditionally, a brand enters into a financial agreement with a media company to have their product displayed in a film or TV show. There are two types of product placement: subtle and prominent, which can also be described as implicit versus explicit product placement (Homer, 2009; d'Astous and Séguin, 1999). Homer (2009) states that a subtle/implicit product placement would include only the visually placed product, whereas the prominent/explicit placement includes the visual image and direct verbal reference to the product (e.g. an actor using and talking about the product).

The final EBE dimension is brand allegiance, which is defined as an employee's future intentions to remain with their organization (King and Grace, 2009; King et al., 2012; King and So, 2013). Similar to the concept of customer loyalty, when employees demonstrate brand allegiance, they have a 
high degree of trust in and loyalty to their organization (Poulis and Wisker, 2016). If employees intend to remain with their organization, they are able to communicate and deliver the organization's brand promise to external stakeholders. Employees who exhibit high brand allegiance demonstrate a commitment to stay with the organization, which is a "future behavioral intention" of EBE (King et al., 2012, p. 273). Based on the theory of reasoned action, Fishbein and Ajzen (1975) argue that behavioral intention is the best predictor of a specific behavior.

King et al. (2012) identify that the ultimate portrayal of EBE is in the concept of brand ambassadorship. While the term "brand ambassador" is not well defined, it generally refers to "[...] a person who acts in the name of a brand" (Schmidt and Baumgarth, 2018, p. 252). Prior research defines a brand ambassador as an employee who represents the corporate brand in all facets of their life (Schade, 2008). Accordingly, a brand ambassador fully embraces and internalizes the brand's values (Foster et al., 2010).

Since EBE's inception, empirically tested scales have been developed that typically rely on data collected from employees through surveys or interviews (Miles and Mangold, 2004; King et al., 2012; Erkmen, 2018). For the purposes of this study, EBE is operationalized using employees' public posts on Instagram. Therefore, this study proposes a novel EBE measure whereby employees' Instagram posts (including images and captions) are assessed using three dimensions: brand consistent behavior, brand endorsement, and brand allegiance (Figure 1).

\section{Method}

This research develops and applies a new method for assessing the three dimensions of EBE using Instagram data. Case study research is an effective method of investigating contemporary events that have not yet been studied (Yin and Campbell, 2018). A single case is examined using a sample of employee influencers (i.e. instructors) who represent the brand at SoulCycle, a leading North American fitness company.

\subsection{Case selection}

Consumers are patronizing fitness and wellness companies more than ever to satiate their need for community and live healthier lifestyles. Thus, the fitness and wellness industry has gained considerable growth in popularity (Biron, 2019). From

Figure 1 Dimensions of employee brand equity

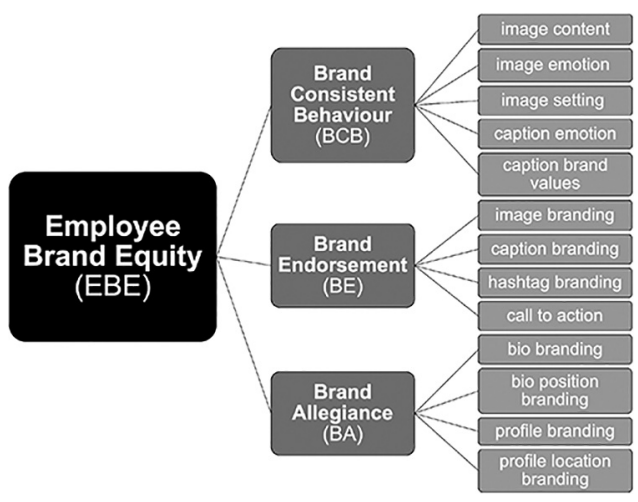

a socioeconomic lens, fitness and wellness are key factors in reducing obesity and costs related to health-care (Dimitrov Ulian et al., 2018). Indeed, fitness and mind-body ranked fourth in 2017 in the economic value of the global wellness industry (US $\$ 595.4 \mathrm{bn}$ ), preceded by wellness tourism, healthy eating and weight loss, and personal care, beauty, and antiaging (Lock, 2020). In the fitness industry, there has been a rise in boutique studios such as SoulCycle, which offer shorter classes due to "time poor" consumers (Roth, 2019).

SoulCycle is an innovative, NY City-based fitness studio that offers indoor cycling classes (Hambrick, 2017). The organization is known for its enlightened, mind, body, and soul approach to fitness and its cult-like appeal (Abad-Santos, 2017). With over 80 studios across the USA, Canada, and the UK, as well as seasonal pop-up locations, SoulCycle offers 45-min classes that provide a full-body workout (Locker, 2017).

SoulCycle's mission is:

[...] to bring Soul to the people. Our one of a kind, rockstar instructors guide riders through an inspirational, meditative fitness experience that's designed to benefit the body, mind and soul. Set in a dark candlelit room to high-energy music, our riders move in unison as a pack to the beat and follow the signature choreography of our instructors. The experience is tribal. It's primal after it's fun. (SoulCycle, 2019)

This research analyzes SoulCycle instructors' activity on Instagram because of their role as employee influencers. SoulCycle instructors are influential front-line employees who personify the brand and are "[...] trained to create a branddefining mood and energy" (Breza et al., 2016, p. 1). SoulCycle prioritizes internal branding practices by investing in their employees. In a highly competitive process, prospective instructors respond to casting calls and enter a rigorous 10-week training program (Hambrick, 2017). Instructors are indoctrinated with the company's unique brand promise of inspiration. As a result, the brand has developed a "cult-like" following with customers and employees alike (Abad-Santos, 2017). SoulCycle and its instructors intentionally have a strong presence on social media - particularly on Instagram, due to the social media platform's brand orientation and its visual and shoppable environment (Day, 2016). Building on prior fitness and wellness research that specifically focuses on Instagram, Instagram is selected as the social media platform of analysis (Tiggemann and Zaccardo, 2018; Deighton-Smith and Bell, 2018; Cohen et al., 2019; Reade, 2020) as influencers, marketers, and brands have identified a preference for Instagram due to its effectiveness for branded content (Sharma, 2017).

\subsection{Sampling}

The SoulCycle website features the names, images, and profiles of each instructor; using the website, the researchers hand compiled an inventory of 315 SoulCycle instructors in August 2018. Using an iterative search process on Instagram, the researchers identified the Instagram handle for instructors with public profiles and recorded the number of followers for each account. A small number of instructors (5.1\%) had private Instagram accounts or no Instagram account, which were excluded for ethical reasons. Table 1 describes the stratified sampling approach (Hair et al., 2014) that was used to categorize the instructors by followers $(0-4,999 ; 5,000-9,999$, and $10,000+$ ).

There is no consensus in the literature on how to identify or segment social media influencers. Vanity metrics such as the 
number of followers, may not be indicative of expertise, the endorser's persuasiveness or personal characteristics that may impact future consumption (De Veirman et al., 2017). This research focuses on instructors with $10,000+$ followers for four reasons. First, SoulCycle instructors with a large number of Instagram followers $(10,000+)$ represent employee influencers. Second, when an account has over $10,000+$ followers, Instagram provides additional technological affordances such as the ability to swipe up to external links. Third, individuals with $10,000+$ followers are prime candidates for analysis as they are well situated in the public domain and may have lower expectations of privacy. Finally, in contrast to the other two categories of followers, instructors with $10,000+$ followers were the only ones to have a verified badge on Instagram (26.3\% of instructors). Four criteria are used to determine if an Instagram account merits a verification badge: authenticity, uniqueness, a public account that is complete, and representation of a notable or highly searched person or brand (Instagram, 2020). Therefore, instructors in the $10,000+$ followers category most closely represent market actors who are well known and have the potential for larger influence based on their following. As such, the research focuses on the instructors in the $10,000+$ followers category.

Within this group of instructors with $10,000+$ followers, a random sample of 10 instructors was selected for analysis. The goal was to analyze 10 images and captions for each instructor, yielding 100 Instagram images, 100 Instagram captions, as well as the bio images and captions for each employee. In qualitative research, there are no universally accepted criteria for determining sample size (Neuendorf, 2017; Sim et al., 2018). Recommendations for determining sample size vary and may be based on techniques such as interviews or focus groups, type of study or other factors. In the absence of guidelines or previous studies that can serve as a reference, some experts suggest that researchers work to the point of theoretical saturation (Sim et al., 2018). This research uses a sample of 100 data points, which exceeds the recommended rules across various types of studies that is typically sufficient to capture all codes at least once, which is the saturation point (Sim et al., 2018; Daniel, 2019).

Despite their public profiles with high followership, the data was anonymized to ensure a high level of research ethics and the captions were rephrased to avoid re-identification. Due to privacy considerations, instructors with private accounts were not included and this research specifically focuses on instructors with the highest number of followers. This research relied solely on secondary data and the organization

Table 1 Instagram instructor profiles ${ }^{\mathrm{a}}$

\begin{tabular}{lcr}
\hline Number of followers & No. of instructors & (\%) \\
\hline $\mathbf{0 - 4 , 9 9 9}$ & 219 & 69.5 \\
$\mathbf{5 , 0 0 0 - 9 , 9 9 9}$ & 42 & 13.3 \\
$\mathbf{1 0 , 0 0 0 +}$ & 38 & 12.1 \\
N/A & 16 & 5.1 \\
Total instructors & 315 & 100.0
\end{tabular}

Notes: ${ }^{a}$ www.soul-cycle.com/ was used to develop an inventory of

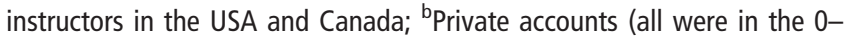
4,999 group) or handles not found
(SoulCycle) was not contacted. The four stages of the data collection process are outlined, as follows:

1 Instagram data scrape: The 10 most recent images and captions for each of the instructors were collected in August 2018, using the software 4k Stogram (Softonic Solutions, 2018), as well as the instructors' profile photos and bios. The 10 most recent images were selected because instructors posted at different frequencies resulting in a different timespan per instructor.

2 Codebook development: A detailed codebook was developed by the researchers to analyze employees' images and captions on Instagram (Appendix). This provided researchers with a standardized means of analyzing the qualitative data (Neuendorf, 2017). A coding schema was modified following Tiggemann and Zaccardo's (2018) study on fitspiration on Instagram to code people, gender, adiposity, muscularity, action, objectification, food, and caption content with respect to fitness. SoulCycle's emotionally related values were addressed using a modified coding schema following Sonne and Erickson's (2018) image and caption emotion codes, which updated the emotion prototypes developed by Shaver et al. (1987). The emotion of the Instagram images was coded with six emotions including happiness, sadness, humor, hard work, thoughtfulness, and neutral; the textual and detailed nature of the captions afforded a more granular coding of 18 emotions (Sonne and Erickson, 2018). The instructors' Instagram bios and captions were also coded for the presence or absence of employer branding.

3 Inter-coder reliability analysis: Following the recommended processes of Neuendorf (2017), extensive coder training, practice sessions, and discussions were conducted. In the first round of coding, two coders independently coded images and captions for six instructors, for a total of 60 images and captions. Discrepancies were discussed and the codebook was refined; a third coder functioned as a consultant, which is recommended to aid definitional clarity (Miles et al., 2014). Inter-rater reliability is a measure for robustness in qualitative research and it is recommended that it is assessed twice (Cornelissen et al., 2012; Neuendorf, 2017). After the first round of coding, inter-rater reliability was measured using Cohen's Kappa. Coders' responses were inputted into SPSS 24 and Cohen's Kappa was calculated at 0.502, which is moderate (Gwet, 2014). After the second round of coding, which followed practice and discussion and resulted in a revised codebook, inter-rater reliability increased to 0.967, which is very high (Gwet, 2014). Subsequent to these two rounds of coding, and based on the high level of inter-rater reliability, one coder completed the coding for four additional instructors, for a total of 40 posts. A total of 100 Instagram images and 100 captions, as well as the bio images and captions for each employee, were included and coded in the data set.

4 Measurement of EBE dimensions: A spreadsheet was used to track the frequencies for each code. This quantitative component is an extension of the analysis and has "[...] the potential to provide a highly valid source of detailed or 'deep' information about a text," image, video, etc. (Neuendorf, 2017, p. 22). Based on the coding categories 
and the criteria established for measuring each item, each of the three dimensions of EBE (brand consistent behavior, brand endorsement, and brand allegiance) were examined and calculated separately. Finally, a total EBE score was calculated by summing the individual scores from the three EBE dimensions.

\subsection{Brand consistent behavior dimension}

For the purposes of this study, and to align with the definition of brand consistent behavior, SoulCycle's brand values are summarized as being health and/or fitness related. Brand consistent behavior was measured by evaluating employees' Instagram posts using the following five items: image content, image emotion, image setting, caption emotion and caption brand values (Appendix).

Therefore, brand consistent behavior includes five items, however, brand endorsement and brand allegiance each include four items, which were equalized for comparative purposes. The five brand consistent behavior items are described below:

Image content: Image content refers to what is in the image and whether the content in the image aligns with the organization's brand values. The objective of this dimension was to identify brand consistent behavior in the context of EBE vis-à-vis the content of the images the employees posted on Instagram. The SoulCycle brand values relate to health and/or fitness, as well as their "rock star" instructors. To measure the content of the image, this research drew upon Tiggemann and Zaccardo's (2018) content analysis of \#fitspiration images on Instagram. Tiggemann and Zaccardo (2018) identified nine image content coded variables: category, food, gender, adiposity, muscularity, action, objectification, quotation content, and dysfunctional quotation. Their coding method was adapted for this research and we identified five codes for image content including posing (fitness related), posing (nonfitness related), posing (body-focused), activity (fitness related) or activity (non-fitness related). If the content of the image was posing (fitness related), posing (body-focused) or activity (fitness related), then it was coded as demonstrating brand consistent behavior.

Image emotion: Image emotion captures whether the emotion in the image demonstrates brand consistent behavior. To assess the emotion of an image, Sonne and Erickson's (2018) image emotion codes, an extension of Shaver et al.'s (1987) typology, were adopted. The six codes for image emotion included: neutral, happiness, hard work, humor, sadness, and thoughtfulness. If the employee's image conveyed happiness, hard work, humor or thoughtfulness, then it was coded as demonstrating brand consistent behavior, whereas employees' images conveying sadness or neutrality were not.

Image setting: Image setting focuses on the location of an image and whether it was situated at the organization. The interiors and exteriors of SoulCycle studios include distinctive visual brand elements such as an iconic logo, a yellow, white, and neon color scheme, the integration of art in the studio spaces, and uplifting designs. The three codes for image setting included: SoulCycle (either inside or outside the studio), not SoulCycle or no setting (e.g. image of a quotation). If the image was set inside or outside a SoulCycle studio, then it was coded as demonstrating brand consistent behavior.

Caption emotion: While image emotion captures the mood or feeling of the image, caption emotion focuses on the mood or feeling conveyed through the text that accompanies the image, including the hashtags. To assess the emotion of the caption, Sonne and Erickson's (2018) 17 text emotion categories for Instagram posts, an extension of Shaver et al.'s (1987) hierarchical tree structure of emotions, were adopted. A neutral category was also included. Therefore, the 18 codes for caption emotion included: excitement, information, humor, love, happiness, gratitude, request, overcoming obstacles, welcoming, anticipation, hard work, sadness, pride, wisdom, satisfaction, surprise, complaint, and neutral. The captions that contained emotions of happiness, excitement, satisfaction, pride, wisdom, gratitude, love, information, request, welcoming, anticipation, surprise, humor, overcoming obstacles or hard work were coded as demonstrating brand consistent behavior, whereas captions coded as neutral, sadness or complaint were not.

Caption brand values: To assess the alignment of the brand values with the caption, the caption was identified as a health and/or fitness related. Two codes for capturing SoulCycle's overarching brand values included: yes or no. For the purposes of this study, with its focus on an organization in the fitness industry, if the caption was health and/or fitness related, then it was coded as demonstrating brand consistent behavior.

\subsection{Brand endorsement dimension}

Brand endorsement, as defined as positive external communication about the brand, was measured by evaluating employees' Instagram posts using the following four items: image branding, caption branding, hashtag branding and call to action (Appendix).

Image branding: While image setting focuses on the location of an image and whether it was taken at the employee's place of work, image branding focuses on whether the employee is showing any branded merchandise such as clothing or accessories, in the image. This can manifest in a branded product, a digital overlay of the logo or words - in the case of an image of text (i.e. a quote). SoulCycle sells various fitness-related apparel (e.g. branded leggings and shirts) that include the SoulCycle logo or the words Soul, SoulCycle or SC. While they also sell other retailers' clothing (e.g. Fila), the brand endorsement dimension focuses on the brand itself, rather than affiliated brands. The four codes for image branding included: SoulCycle + other company; Only SoulCycle; Other brands; No. If the brand appears in the image (codes: SoulCycle + other company or Only SoulCycle), then it was coded as contributing to brand endorsement.

Caption branding: Similar to image branding, caption branding also captures whether the employee is explicitly showcasing the brand in the post, except the focus is on the text-based caption. The four codes for image branding included: SoulCycle + other company; Only SoulCycle; Other brands; No. If the brand appears in the text (codes: SoulCycle + other company or Only SoulCycle), then it was coded as contributing to brand endorsement.

Hashtag branding: Hashtag branding signals that the user wants to be publicly affiliated with the brand. A hashtag refers 
to a conversational marker that adds a post to an existing topical discourse that is independent of a follower/followee network (Jacobson and Mascaro, 2016). In practice, when a user with a public profile adds a hashtag to their post on social media, the post becomes searchable and findable to other users who are interested in that topic and searchable for posts using that hashtag. In 2017, Instagram updated its platform so users could follow a hashtag of interest, which means the platform's algorithm selects and showcases the posts in the user's main feed. A branded hashtag manifests as a \#[alphanumeric text] that explicitly mentions the brand (e.g. \#SoulCycle). The four codes for hashtag branding included: SoulCycle + other company; Only SoulCycle; Other brands; No. If the brand appears in the hashtag (codes: SoulCycle + other company or Only SoulCycle), then it was coded as contributing to brand endorsement.

Call to action: A call to action refers to an offer or demand that directly speaks to the audience, compelling them to act. The four codes for the call to action included: SoulCycle Related; Non-SoulCycle Related - Professional; Non-SoulCycle Related - Personal; No. If there was a call to action related to the brand (code: SoulCycle Related), then it was coded as contributing to brand endorsement.

\subsection{Brand allegiance dimension}

Brand allegiance is operationalized by focusing on the employee's profile (Table 6). The profile includes a profile photo and a text-based bio (short-form for biography) that represent relatively stable identity markers. Importantly, the profile page is always visible on Instagram, irrespective of privacy settings. As such, the profile page is important in that it reflects how an individual chooses to holistically represent themselves. Publicly available profiles have been used as a predictor of personality as individuals reveal a lot of information about themselves in their profiles (Golbeck et al., 2011). As the profile is more stable and over-arching as an identity marker, brand allegiance is operationalized by focusing on the profile.

Brand allegiance dimension includes the following four items: bio branding, bio position branding, profile branding and profile location branding (Appendix).

Each of the four items was coded as a binary $(1=$ yes; $0=$ no). The first two items relate to the text-based bio and the final two items relate to the profile photo.

Bio branding: Bio branding identifies whether the employer is mentioned in the bio, including hashtags, tagged usernames or any other mention of the brand. By mentioning the employer in the bio, the employee is choosing to self-identify with the employer and may reflect their future intentions to remain with the organization.

Bio position branding: Bio position branding captures whether the employee is a more senior, higher-level employee within the organization. Specifically, we analyze if the employee states they are a master or senior instructor, which may reflect their future intention to remain with the organization.

Profile branding: Shifting to the profile photo, profile branding captures whether the employee is wearing or using any company branded merchandise or displaying their company logo in the profile photo. Electing to showcase branded items in one's profile photo is a sign of brand allegiance.
Profile location branding: Finally, profile location branding captures whether the company or a company logo is visible in the background of the employee's profile photo. Electing to have one's profile photo taken at their company is a sign of brand allegiance.

\section{Findings}

While traditional EBE scales tend to rely on data collected directly from employees, the findings of this research highlight how EBE can be linked to employees' social media activity. As such, the findings below offer an evolution of King et al.'s (2012) model using publicly available Instagram data. The total EBE scores for the SoulCycle instructors ranged from 2.80 to 5.73 out of 10 . Of the three dimensions, brand consistent behavior achieved the highest scores overall with the smallest range and the highest median. While brand allegiance had the second-highest median (5 out of 10 ), three employees scored very low in this category. Brand endorsement had the lowest median (3.25 out of 10), but the range for this category was in the middle of the other two dimensions. Some of the items are reported based on the number of employees $(n=10)$, and other items are reported based on the number of posts $(n=$ $100)$; for clarity, they are also reported as a percentage. The median score is reported based on the total employee sample. The Appendix provides anonymized examples from the data set. In the following sections, the findings of each of the three dimensions of EBE are highlighted: brand consistent behavior, brand endorsement and brand allegiance.

\subsection{Brand consistent behavior findings}

The brand consistent behavior dimension ranged from 5.8 to 7.8 out of 10 per employee with a median score of 6.3 . The results of the five items used to measure brand consistent behavior are summarized below (Tables 2-3):

Image content: $66 \%(n=66)$ of images showcased fitnessrelated posing, fitness-related activities or body-focused posing. Between $0 \%$ and $100 \%$ of individual employee's posts contained images that aligned with SoulCycle's brand values. The median score was $70 \%(n=7)$.

Image emotion: The majority $(89 \%, n=89)$ of images showcased emotions that are aligned with brand consistent behaviors such as happiness, hard work, humor, and thoughtfulness. The median score was $90 \%(n=9)$.

Image setting: This is the lowest scoring item for brand consistent behavior. Only $18 \%(n=18)$ of employees' posts featured the interior or exterior of a SoulCycle studio. In total, 2 out of 10 employees did not have any images set inside or outside a SoulCycle studio. The median score was 20\% $(n=2)$.

Caption emotion: $94 \%(n=94)$ of employees' captions contained emotions that are aligned with SoulCycle's brand values. In total, 7 out of 10 employees had $100 \%$ of their captions containing emotions that represent SoulCycle values. This is the highest-scoring item for brand consistent behavior.

Caption brand values: $66 \%(n=66)$ of captions were health and/or fitness related. Between $30 \%$ and $100 \%$ of employees' captions contained health and/or fitness-related information. The median score was $60 \%(n=6)$. 
Table 2 Brand consistent behavior (BCB) by instructor

\begin{tabular}{lcccccc}
\hline Pseudonym & Image content & Image emotion & Image setting & Caption emotion & Health/fitness caption & BCB total instructor (out of 10) \\
\hline Employee 1 & 9 & 10 & 2 & 9 & 6 & 9 \\
Employee 2 & 8 & 10 & 2 & 10 & 9 & 7.2 \\
Employee 3 & 10 & 8 & 1 & 10 & 6 & 7.8 \\
Employee 4 & 4 & 8 & 3 & 10 & 7 & 6.2 \\
Employee 5 & 4 & 8 & 3 & 10 & 6 & 6.4 \\
Employee 6 & 4 & 7 & 2 & 10 & 3 & 6.8 \\
Employee 7 & 8 & 10 & 3 & 7 & 6 & 6.2 \\
Employee 8 & 5 & 9 & 0 & 8 & 4 & 6.0 \\
Employee 9 & 6 & 10 & 2 & 10 & 10 & 7.4 \\
Employee 10 & 8 & 9 & 0 &
\end{tabular}

Table 3 BCB summary

\begin{tabular}{|c|c|c|c|c|c|c|}
\hline Values & Health/fitness caption & Image content & Image emotion & Image setting & Caption emotion & $\mathrm{BCB}$ total instructor (out of 10 ) \\
\hline Min & 3 & 4 & 7 & 0 & 7 & 5.8 \\
\hline Max & 10 & 10 & 10 & 3 & 10 & 7.8 \\
\hline Range & 7 & 6 & 3 & 3 & 3 & 2.0 \\
\hline Median & 6 & 7 & 9 & 2 & 10 & 6.3 \\
\hline Total & 66 & 66 & 89 & 18 & 94 & \\
\hline
\end{tabular}

\subsection{Brand endorsement findings}

The brand endorsement dimension ranged from 0.5 to 4.5 out of 10 per employee with a median score of 3.25. The results of the four items used to measure brand endorsement are summarized below (Tables 4-5):

Image branding: $21 \%$ of posts $(n=21)$ showcased SoulCycle branded merchandise. Between $0 \%$ and $40 \%$ of individual employee's posts had image branding and a median score of $20 \%(n=2)$.
Caption branding: $33 \%$ of posts $(n=33)$ explicitly showcased SoulCycle in the text-based caption. Between $0 \%$ and $60 \%$ of individual employee's posts had caption branding and a median score of $40 \%(n=4)$.

Hashtag branding: $48 \%$ of posts $(n=48)$ included a SoulCyclerelated hashtag in the caption. Between $10 \%$ and $80 \%$ of individual employee's posts had hashtag branding and a median score of $50 \%$ $(n=5)$. Almost half of the posts included hashtag branding and this is the highest-scoring item for brand endorsement.

Table 4 Brand endorsement (BE) by instructor

\begin{tabular}{lccccc}
\hline Pseudonym & Image branding & Caption branding & Hashtag branding & Call to action & BE total instructor (out of 10) \\
\hline Employee 1 & 4.00 & 5.00 & 1.00 & 0.00 & 2.50 \\
Employee 2 & 2.00 & 6.00 & 5.00 & 3.00 & 0.00 \\
Employee 3 & 2.00 & 5.00 & 6.00 & 5.00 & 3.00 \\
Employee 4 & 3.00 & 4.00 & 6.00 & 1.00 & 4.50 \\
Employee 5 & 3.00 & 4.00 & 7.00 & 2.00 & 3.75 \\
Employee 6 & 2.00 & 4.00 & 5.00 & 1.00 & 3.25 \\
Employee 7 & 3.00 & 0.00 & 8.00 & 0.00 & 3.75 \\
Employee 8 & 0.00 & 1.00 & 5.00 & 0.00 & 0.50 \\
Employee 9 & 2.00 & 1.00 & 3.00 & 0.00 & 2.00 \\
Employee 10 & 0.00 & &
\end{tabular}

Table 5 BE summary

\begin{tabular}{lccccc}
\hline Values & Image branding & Caption branding & Hashtag branding & Call to action & BE total instructor (out of 10) \\
\hline Min & 0 & 0 & 1 & 0 & 0.50 \\
Max & 4 & 6 & 8 & 5 & 4.50 \\
Range & 4 & 6 & 7 & 5 & 4.00 \\
Median & 2 & 4 & 5 & 12 & 3.25 \\
Total & 21 & 33 & 48 & \\
\hline
\end{tabular}


Call to action: Call to action was the lowest scoring item for brand endorsement. In total, $12 \%$ of posts $(n=12)$ included a SoulCycle-related call to action in the caption. Between $0 \%$ and $50 \%$ of individual employee's posts had a call to action and there was a median score of $5 \%(n=0.5)$.

\subsection{Brand allegiance findings}

The brand allegiance dimension ranged from 0.0 to 7.5 out of 10 per employee with a median score of 5.0. The results of the four items used to measure brand allegiance are summarized below (Table 6):

Bio branding: 90\% $(n=9)$ of employees included SoulCycle in their Instagram bio. Most employees chose to affiliate themselves with SoulCycle in their Instagram bio and this was the highestscoring item for brand allegiance.

Bio position branding: $30 \%(n=3)$ of employees included their rank as master or senior instructors in their Instagram bio.

Profile branding: $30 \%(n=3)$ of employees were wearing or using SoulCycle branded merchandise in their profile photos such as branded clothing or accessories.

Profile location branding: Profile location branding was the lowest scoring item for brand allegiance. Only 20\% $(n=2)$ of employees had the SoulCycle studio or logo visible in the background of the profile.

\section{Discussion}

The research has operationalized and applied the three EBE dimensions - brand consistent behavior, brand endorsement, and brand allegiance - using Instagram data. Figure 2 and Table 7 summarize research results. The following section provides an analysis of the importance and meaning of the findings as an expansion of King et al.'s (2012) model to social media data.

\subsection{Brand consistent behavior discussion}

In this study, brand consistent behavior is measured by evaluating employees' Instagram posts including the content, emotion, and setting of the image, and the emotion and brand values of the caption. For example, an employee may post an image showing them engaged in a fitness activity or post inspirational quotes about living a healthy and meaningful life. Of the three EBE dimensions measured in this study, brand consistent behavior was the highest: the majority of the employees' images and captions showcased content that was aligned with SoulCycle's brand values. The emotions of the captions and images are highly aligned with the brand values ( $94 \%$ and $89 \%$, respectively). Over half of the images and captions are aligned with the brand's values like health and/or fitness-related (66\%). The weakest area of the brand consistent behavior dimension was image setting where only $18 \%$ of employees' images featured the interior or exterior of a SoulCycle studio. It is, however, not surprising that image setting received the lowest score; based on industry reports, SoulCycle employees are not compensated for their Instagram activity and their posts include both personal and professional content.

An important element of brand consistent behavior is the congruency of the employee's values with the organization's brand values. Previous studies have also found when employees espouse values that are aligned with their organization's it motivates greater levels of brand value co-creation (Merrilees et al., 2017; Edvardsson et al., 2011). From an organizational perspective, there does not appear to be any negative consequences for an employee having a very high score for brand consistent behavior. Therefore, higher brand consistent behavior scores could be leveraged by an organization to further enhance their internal branding initiatives and better understand how their employees contribute to the co-creation of brand value. This study has developed a novel method to measure brand consistent behavior on Instagram and provides employers a method to periodically holistically understand how well aligned their employees' posts (i.e. images and captions) are with their brand values over time. With the consent of employees, the proposed brand consistent behavior dimension enables organizations to identify, develop, and nurture high scoring employees into future brand ambassadors or advocates.

\subsection{Brand endorsement discussion}

Of the three EBE dimensions assessed in this study, brand endorsement had the lowest score. In this research, there was evidence of both implicit and explicit product placement. For example, an implicit product placement would be the visual display of SoulCycle branded merchandise (i.e. image branding); an explicit product placement would be an explicit text-based reference to SoulCycle (i.e. caption branding, hashtag branding, and call to action). This research posits that a lower level of brand endorsement (i.e. product placement) may indicate a higher level of perceived authenticity from a consumer perspective, which is a desirable attribute (Audrezet et al., 2020). Brand authenticity in human brands was an

Table 6 Brand allegiance (BA) by instructor

\begin{tabular}{lccccc}
\hline Pseudonym & Bio branding & Profile branding & Profile location branding & Bio position branding & BA total (out of 10) \\
\hline Employee 1 & 1 & 1 & 1 & 0 & 1 \\
Employee 2 & 1 & 0 & 0 & 0 & 7.5 \\
Employee 3 & 1 & 1 & 0 & 0 & 5.0 \\
Employee 4 & 1 & 1 & 1 & 0 & 5.0 \\
Employee 5 & 1 & 0 & 0 & 0 & 5.0 \\
Employee 6 & 1 & 0 & 0 & 1 & 5.0 \\
Employee 7 & 1 & 0 & 0 & 0 & 2.5 \\
Employee 8 & 1 & 0 & 0 & 0 & 5.0 \\
Employee 9 & 1 & 0 & 0 & 0 & 0.0 \\
Employee 10 & 0 & 0 & & 0 \\
\hline
\end{tabular}


Figure 2 Total EBE by instructor summary

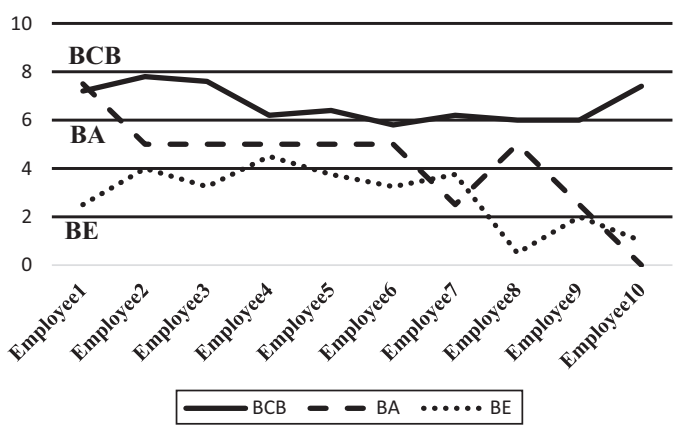

Table 7 Total EBE summary

\begin{tabular}{lcccc}
\hline Values & $\begin{array}{c}\text { BCB } \\
\text { (out of 10) }\end{array}$ & $\begin{array}{c}\text { BA } \\
\text { (out of 10) }\end{array}$ & $\begin{array}{c}\text { BE } \\
\text { (out of 10) }\end{array}$ & $\begin{array}{c}\text { Total EBE } \\
\text { (out of 10) }\end{array}$ \\
\hline Min & 5.80 & 0.00 & 0.50 & 2.80 \\
Max & 7.80 & 7.50 & 4.50 & 5.73 \\
Range & 2.00 & 7.50 & 4.00 & 2.93 \\
Median & 6.30 & 5.00 & 3.25 & 4.87 \\
\hline
\end{tabular}

antecedent of trust in empirical research conducted by Moulard et al., 2016. Research by Kowalczyk and Pounders (2016) demonstrated that authenticity in celebrities' social media postings resulted in a positive emotional attachment and posited that this would likely lead to purchase intent. Repetition of prominent brand placement can be negatively perceived as "'too obvious' and 'in your face"” (Homer, 2009, p. 29). As such, there is a possible negative implication for a very high brand endorsement score; the audience may become fatigued with the incessant "advertising." Employees who display excessive positive endorsement about their employer may be viewed as lacking authenticity or being "spammy." Perceived authenticity is important for social media followers and an individual's authenticity may be threatened when branded behavior creeps into their content (Audrezet et al., 2020). As such, this research anticipates that brand endorsement will likely be the lowest-ranked dimension for many organizations. Brand endorsement was the lowest scoring item in this study of SoulCycle employees, but brand endorsement greatly varied among employees. A healthy employee brand score on social media would, therefore, necessitate that brand endorsement is lower than the other two dimensions. From a value co-creation perspective, brand endorsement could be interpreted as employees who are empowered and engaged with the brand in a positive way. While there are no negative implications for an employee having a high brand consistent behavior or brand allegiance score, a very high brand endorsement score may threaten an employee's authenticity and credibility.

The call to action was the lowest scoring item in the brand endorsement measure (12\%), yet the score may still be considered relatively high as this item is an explicit prompt to the audience to act and engage with SoulCycle. This often appeared as the employee posting about their upcoming class times, which is the most direct form of advertisement that encourages a response from the audience. It is important to consider that these employees are "electing" to engage (i.e. extra-role) in this behavior. As such, posts engaged in advertising behavior on behalf of the employer, yet they were not labeled as sponsored. In Canada, Ad Standards (2019) states that there needs to be an explicit disclosure on social media posts when there is a material connection:

Any connection between an entity providing a product or service and an endorser, reviewer, influencer or person making a representation that may affect the weight or credibility of the representation, and includes: benefits and incentives such as monetary or other compensation, free products with or without any conditions attached, discounts, gifts, contest and sweepstakes entries, and any employment relationship (p. 5, emphasis added).

The Federal Trade Commission in the USA has similar guidelines (FTC, 2017). While legislating bodies directly recognize the employment relationship, in the current social media landscape, employees generally do not post disclosure statements when they post about their employer, but the employee-employer relationship does represent a material connection. None of the posts in our sample included a disclosure statement. The norms surrounding this practice may change as employee brand endorsement on social media becomes more prevalent and regulators begin to take further notice and action.

\subsection{Brand allegiance discussion}

In this research, brand allegiance is assessed through the lens of the employee's public Instagram profile, which represents a stable component of the platform that is not frequently updated. The results of this research showed that almost all SoulCycle instructors (90\%) brand their Instagram bio with the name of their employer. SoulCycle instructors' strong professional identity and relationship with the brand represents how they see themselves and how they want to be seen by their followers. This may be augmented by adding their position within the organization, using the studio as the background for their profile picture, and/or wearing SoulCycle branded merchandise. Thus, this research posits that brand allegiance behavior demonstrates employees' enduring brand identification and internalization, which are two important components of employee brand commitment based on behavior (Burmann et al., 2009) and a proxy for future intention to remain with the company.

A company whose employees demonstrate high brand allegiance represents a workforce that is committed to remaining with the organization and has the potential to cocreate value in the long-term. The profile and bio are purposeful; they represent how the employees see themselves and how they want to be seen by their followers. When the profile photo or bio includes the employer's corporate brand, the employer is part of how the employee sees themselves their identity - and how they want to be seen by others.

The examination of brand allegiance by analyzing the employee's Instagram profile is a key contribution of this research. Prior research on studying organizations and influencers on Instagram examines posts from diverse perspectives, including self-presentation, content variables, and hashtag use, but tends to exclude bios and profile pictures (Russmann and Svensson, 2016; Erz et al., 2018; Harris and Bardey, 2019). Importantly, the Instagram profile is always 
publicly available, even when the account is private, which means that it is the only piece of information that is available to all people who search on Instagram. As a social footprint, it represents traces of user-generated content on social media and merits analysis (Tuten and Solomon, 2018).

Brand allegiance speaks to future intention and this research operationalizes brand allegiance using past behavior as a predictor of future intention. This research contends that an employee who elects to self-disclose and identify with their employer in the bio is more committed to the brand, contributes to value co-creation and is, therefore, more likely to stay with the company in the future.

\section{Conclusion}

This research operationalizes EBE on social media by examining how employee influencers from a leading company in the health and fitness industry use Instagram to post workrelated content. Companies can use the relative three scores in the three dimensions (brand consistent behavior, brand endorsement, and brand allegiance) to assess their EBE using their employees' public data on Instagram. The scores, however, are not as meaningful when viewed as a snapshot. If the numbers were tracked over time even the weakest areas of behavior could be considered relatively good, especially if the scores improved over time. Therefore, if an EBE score improves over time, the company is benefiting from its employees' behaviors from both brand building and brand value co-creation perspectives.

When using employees' public Instagram data, as is done in this research, a high EBE score can be the ultimate display of brand ambassadorship in a social media age. Brand ambassadors are loyal to the brand; they are willing to use their brand in their professional and personal lives, recommend the brand to others (Schade, 2008) and contribute to the cocreation of brand value (Hatch and Schultz, 2010). Employees are forming strong relationships with their employers and this research's operationalization of EBE can be used to assess the level of brand ambassadorship. Using the proposed measure of EBE, employees need activity in all three EBE dimensions to be considered brand ambassadors: brand consistent behavior (what employees do), brand endorsement (what employees say), and brand allegiance (what employees intend to do in the future) (King et al., 2012). Employees need to have activity in all three dimensions of EBE as this is the intangible assessment of the brand from the employees' perspectives.

An employee with a high score in only one of the three dimensions does not signify brand ambassadorship. For example, having high brand consistent behavior alone does not establish that an employee is demonstrating brand ambassadorship. Even though brand ambassadors and employees who demonstrate brand consistent behavior can both be interpreted as "living the brand," which is an important part of asserting authority and authenticity, brand ambassadors fully embrace, internalize, and identify with the brand's values. Thus, they are also taking on the role of employee influencers of the corporate brand. The brand consistent behavior dimension alone does not assess loyalty (brand allegiance) or whether the employee is specifically recommending the brand to others (brand endorsement). King and Grace (2009) suggest employers seek to recruit brand-oriented employees who demonstrate positive behaviors toward their organization's brand and identify and develop future brand ambassadors among their current employees. As such, when brand consistent behavior is combined with brand allegiance and brand endorsement (which involves explicit and implicit recommendations of the employer), a more complete measure of brand ambassadorship can be assessed.

There are logical reasons and tangible benefits for an employee engaging in brand ambassadorship for their employer on social media. First, this type of employee behavior may be positively regarded by the employer. In fact, an employer could set up a compensation or rewards system to promote this type of behavior. This practice may become more common in workplaces over time. Even without the explicit compensation system, if a critical mass of employees engages in this behavior, then it may create an unspoken social norm in workplaces and employees may feel pressure to also engage in the activity. Second, an employee may derive direct benefit from this behavior on social media such as driving people to their class, which, in turn, makes the class more popular and may increase future employment opportunities (such as teaching additional classes). Third, an employee may derive indirect benefits from this behavior such as building their following on social media and improving their personal brand (Jacobson, 2020; Wee and Brooks, 2010), which may lead to other personal and/or professional opportunities.

With the proliferation of employees posting information about their employers' corporate brands on social media platforms such as Instagram, there needs to be further scholarly and industry recognition of the significance of this type of employee engagement and influence. Frontline employee behavior represents an important personification of a brand and contributes to the co-creation of brand value, yet employers typically do not have direct control over their employees' social media activities. The trend toward individuals connecting with brands on social media is likely to continue, thus social media will continue to play a critical role in value co-creation and for connecting brands, employees, and consumers. Similarly, the emerging trend of employees articulating their brand voice on social media as employee influencers and posting work-related content is likely to become more prevalent.

Social norms may develop over time resulting in it becoming a normative convention to promote and discuss one's employer on social media. The proliferation of this behavior on social media raises questions about the ethics of employees posting for their companies, the compensation of such practices, and the transparency of employers asking or requiring employees to post.

\subsection{Theoretical contributions}

An important scholarly contribution of the research is the operationalization and application of EBE using public social media data; this represents a significant expansion and evolution of King et al.'s (2012) model. Building on previous research that operationalizes EBE using employees' self-report data, this research introduces a new measure of EBE that does not require employers to survey or interview their employees, which may support the internal validity of the data or reduce the bias - such as social desirability bias - that is often found in self-report data. 
The research offers an extension and modification to EBE that can be used in future research. Our measure of EBE can be adapted to other companies and industries and the authors hope that it will be productively used by future researchers to analyze other industries, as well as locations. Beyond analyzing Instagram data, the EBE measure can also be adapted to other social media platforms that include both text and visuals such as Twitter, TikTok, and Glassdoor.com.

\subsection{Managerial implications}

Employees are expressing their opinions on social media and this new form of employee voice is important for employers to hear. As a practical implication of the research, organizations can use the measure to holistically identify, track, manage, and measure how aligned their employees' behaviors are with their brand and better understand how employees contribute to the brand value co-creation process. From a managerial perspective, previous research suggests internal branding has a positive impact on firm performance (Piehler et al., 2018). While EBE has been regarded as a competitive differentiator, research has demonstrated its positive impact on firm performance, measured through sales, market share, profitability, customers' satisfaction, and new market entry (Poulis and Wisker, 2016). An organization that fosters "innovative and spontaneous" behaviors prevents stagnation and myopia within the organization (Katz, 1964, p. 132). Employee empowerment is consistently cited as a key success factor for frontline employees, in both theory (Spreitzer, 1995; Maynard et al., 2012; Auh et al., 2014; Altaf and Shahzad, 2018) and practice (Sadri, 2012; Tschohl, 1998, 2018) resulting in consumer trust, loyalty, and sales success (Tschohl, 1998; Spector and McCarthy, 2000). As such, employers that ethically assess their EBE using social media data can gain an advantage; the EBE measure proposed in this research can be used to assist this practice.

In this case study, the absolute numbers provide insight into SoulCycle by analyzing their employees' brand consistent behavior, brand endorsement, and brand allegiance behaviors. Beyond a snapshot in time, the data can insightfully be used in a longitudinal or comparative study of clusters of employees (e.g. locations, types of employees, and competitors) to understand employees' changing behavior as it manifests on social media. Problematically, many organizations may not want to engage in a long-term endeavor to understand their employees' behavior on social media and how this relates to EBE. This type of analysis, which mirrors an internal audit, necessitates a longerterm investment to measure EBE over time. There are future opportunities to combine the research approach described here with automated social listening tools (Kübler et al., 2020).

Given the trend toward big data analysis (Grewal et al., 2017), this research also recognizes significant ethical challenges with employers analyzing their employees' social media posts. Even though the data is publicly available, individuals may not feel comfortable with third parties such as employers, analyzing their content (Dubois et al., 2020; Jacobson et al., 2020).

Any research and subsequent analysis by employers should only use publicly available social media data. With that being said, just because social media data is public does not mean that individuals do not have context-specific expectations of privacy
(Gruzd et al., 2020). As described in the methods section, the research specifically focuses on employees with $10,000+$ followers as they are well situated within the public domain and may have lower privacy expectations due to their influencer status. As a managerial practice, the researchers urge employers to similarly only focus on their more public-facing employees with a high following and further seek explicit permission from their employees to analyze their public social media data in a move toward transparency and ethical data practices.

Employers could seek out third parties to conduct the analysis on their behalf and only share anonymized data with the company. In this way, a company can assess its EBE, but the data would not be linked to any specific employee - similar to anonymous employee satisfaction surveys. Significant ethical consideration is required to ensure employees' privacy and autonomy is respected, and this is an important area for future research.

\subsection{Limitations and future research directions}

While this research provides a new perspective on measuring each component of EBE, it has limitations. From a methodological perspective, a single case study approach was used. The research advances theory and practice, but it may not be generalized from a statistical perspective to make an inference about a population (Yin and Campbell, 2018). Future research (e.g. competitors and other industries) will help researchers identify patterns that may lead to empirical generalizations (Buchanan, 2012).

The research's unique approach to operationalize the three dimensions of EBE using Instagram data is not without its limitations. While the research develops and applies the method, it was not evaluated. Future research should seek to do so, and other researchers are encouraged to apply and test the method in other contexts. While brand endorsement and brand consistent behavior can justifiably be operationalized using employees' past photos, there are challenges to operationalizing brand allegiance. Predicting future behavior can be problematic and previous EBE research uses self-reporting data by asking employees what they intend to do. This can be problematic as self-report bias is widely recognized in previous research (Donaldson and Grant-Vallone, 2002). Furthermore, within the context of an employee being asked about their future intentions to remain with an organization, they may feel compelled to respond in a socially desirable way, which further confounds the research (van de Mortel, 2008). The approach proposed in this research relies on employees' past behavior as a predictor of future behavior; previous research suggests that past behavior is the strongest predictor of future behavior (Ouellette and Wood, 1998). Nevertheless, predicting future behavior is intrinsically difficult and a limitation of this research.

This research focused on analyzing SoulCycle's brand values manifested on Instagram, through the voice of influential employee instructors. The researchers, however, did not explore employees' negative brand behavior or sentiment on social media and how the organization might mitigate these types of issues. Pitt et al. (2019) recommend employers also focus on understanding employees' negative brand behaviors. Tracking employees' social media activities has risks; employers need to be prepared to hear the negative 
perceptions, or the "dark side," of their brand as employees' perceptions may be different than anticipated. While using social media to measure employee voice is new, there are traditional methods that include stakeholders such as customers and supervisors, that were not used in this research (i.e. employee satisfaction surveys or customer perceptions of how employees are delivering the brand promise) (Holland et al., 2016).

While the employee influencer behavior can be seen on various social media platforms, this research focused on Instagram data, which includes both visual and textual data. The proposed EBE measure may need adaptation, testing, and validation if it were applied to a different social media platform or sector and the authors hope other researchers will continue to build on this. The research did not analyze followers' comments because the focus was on employee behavior and the development of the measure of EBE using public Instagram data. Future researchers may examine the outcomes of employee behavior by analyzing audience behavior. Furthermore, another line of research can interview corporate experts to help nuance the findings.

Future work could test and refine the EBE measure on social media in a larger sample segmented by followers and applied to multiple organizations. It is important to develop best practices, including ethical considerations, especially considering a brand endorsement. Additional research could consider success factors for management and employee empowerment and engagement in industries where frontline employees play a key role in fostering consumer trust and loyalty. This would assist managers and scholars who seek to determine if EBE manifested on social media is a differentiator, and, perhaps, a substantive driver of performance in organizations.

\section{References}

Aaker, D.A. (1992), Managing Brand Equity: Capitalizing on the Value of a Brand Name, The Free Press, New York, NY.

Abad-Santos, A. (2017), "SoulCycle, explained", available at: www.vox.com/2015/6/4/8725447/soulcycle-explained (accessed 27 March 2020).

Ad Standards (2019), "Disclosure guidelines", available at: http://adstandards.ca/wp-content/uploads/2019/02/ Influencer-Marketing-Steering-Committee-DisclosureGuidelines-Jan-2019.pdf (accessed 20 October 2019).

Altaf, M. and Shahzad, A. (2018), “'That's my job' exploring the effect of brand empowerment towards employee brand equity: mediating role of employee critical psychological states", Review of Business Management, Vol. 20 No. 4, pp. 599-618.

Anselmsson, J., Burt, S. and Tunca, B. (2017), “An integrated retailer image and brand equity framework: re-examining, extending, and restructuring retailer brand equity", fournal of Retailing and Consumer Services, Vol. 38, pp. 194-203.

Audrezet, A., de Kerviler, G. and Guidry Moulard, J. (2020), "Authenticity under threat: when social media influencers need to go beyond self-presentation", Fournal of Business Research, Vol. 117, pp. 557-569.

Auh, S., Menguc, B. and Jung, Y.S. (2014), "Unpacking the relationship between empowering leadership and service- oriented citizenship behaviors: a multilevel approach", Fournal of the Academy of Marketing Science, Vol. 42 No. 5, pp. 558-579.

Badrinarayanan, V. and Laverie, D.A. (2011), "Brand advocacy and sales effort by retail salespeople: antecedents and influence of identification with manufacturers' brands", Fournal of Personal Selling $\mathcal{E}$ Sales Management, Vol. 31 No. 2, pp. 123-140.

Baumgarth, C. and Schmidt, M. (2010), "How strong is the business-to-business brand in the workforce? An empiricallytested model of 'internal brand equity' in a business-tobusiness setting", Industrial Marketing Management, Vol. 39 No. 8, pp. 1250-1260.

Biron, B. (2019), "Fitness has exploded into a nearly $\$ 100$ billion global industry as more people become obsessed with their health", available at: www.businessinsider.com/fitnesshas-exploded-into-a-nearly-100-billion-global-industry-20199 (accessed 3 September 2019).

Boukis, A. and Christodoulides, G. (2020), "Investigating key antecedents and outcomes of employee-based brand equity: antecedents and outcomes of employee-based brand equity", European Management Review, Vol. 17 No. 1, pp. 41-55.

Brexendorf, T.O. and Kernstock, J. (2007), "Corporate behaviour vs brand behaviour: towards an integrated view?", Fournal of Brand Management, Vol. 15 No. 1, pp. 32-40.

Breza, E. Hertzberg, A. and Jones, C. (2016), "Valuing SoulCycle. Harvard business review case study", Columbia Business School, available at: https://store.hbr.org/product/ valuing-soulcycle/cu176?sku=CU176-PDF-ENG (accessed 14 May 2019).

Buchanan, D.A. (2012), "Case studies in organizational research", in Symon, G. and Cassell, C. (Eds), Qualitative Organizational Research: core Methods and Current Challenges, Sage, pp. 351-370.

Burmann, C. and Zeplin, S. (2005), "Building brand commitment: a behavioural approach to internal brand management", Fournal of Brand Management, Vol. 12 No. 4, pp. 279-300.

Burmann, C., Zeplin, S. and Riley, N. (2009), "Key determinants of internal brand management success: an exploratory empirical analysis", Fournal of Brand Management, Vol. 16 No. 4, pp. 264-284.

Chou, C.Y., Huang, C.H. and Lin, T. (2018), "Organizational intellectual capital and its relation to frontline service employee innovative behavior: consumer value co-creation behavior as a moderator", Service Business, Vol. 12 No. 4, pp. 663-684.

Clement, J. (2020), “Most popular social networks worldwide as of january 2020, ranked by number of active users”, available at: www.statista.com/statistics/272014/global-social-networksranked-by-number-of-users/ (accessed 20 March 2020).

Cohen, R., Irwin, L., Newton-John, T. and Slater, A. (2019), "\#bodypositivity: a content analysis of body positive accounts on Instagram”, Body Image, Vol. 29, pp. 47-57.

Cornelissen, J., Mattos, G.D., Piekkari, R. and Welch, C. (2012), "Writing up as a legitimacy seeking process: alternative publishing recipes for qualitative research", in Symon, G. and Cassell, C. (Eds), Qualitative Organizational Research: core Methods and Current Challenges, SAGE, pp. 185-203. 
D’Astous, A. and Séguin, N. (1999), “Consumer reactions to product placement strategies in television sponsorship", European fournal of Marketing, Vol. 33 Nos 9/10, pp. 896-910.

Daniel, B.K. (2019), "Student experience of the maximum variation framework for determining sample size in qualitative research", Paper presented at the European Conference on Research Methodology for Business and Management Studies, Kidmore End, pp. 92-100.

Day, C. (2016), "These fitness brands on Instagram pump hard (and you can, too!)", available at: www.agorapulse.com/blog/ fitness-brands-instagram/ (accessed 14 March 2020).

de Chernatony, L. and Dall'Olmo Riley, F. (1999), "Experts' views about defining services brands and the principles of services branding", fournal of Business Research, Vol. 46 No. 2, pp. 181-192.

De Veirman, M., Cauberghe, V. and Hudders, L. (2017), "Marketing through Instagram influencers: the impact of number of followers and product divergence on brand attitude", International fournal of Advertising, Vol. 36 No. 5, pp. 798-828.

Deighton-Smith, N. and Bell, B.T. (2018), "Objectifying fitness: a content and thematic analysis of \#fitspiration images on social media", Psychology of Popular Media Culture, Vol. 7 No. 4, pp. 467-483.

Dimitrov Ulian, M., Pinto, A.J., de Morais Sato, P., B., Benatti, F., Lopes de Campos-Ferraz, P., Coelho, D., Roble, O.J., Sabatini, F., Perez, I., Aburad, L., Vessoni, A., Fernandez Unsain, R., Macedo Rogero, M., Toporcov, T.N., de SáPinto, A.L., Gualano, B. and Scagliusi, F. (2018), "Effects of a new intervention based on the health at every size approach for the management of obesity: the 'health and wellness in obesity' study”, Plos One, Vol. 13 No. 7, p. e0198401.

Donaldson, S.I. and Grant-Vallone, E.J. (2002), "Understanding self-report bias in organizational behavior research", fournal of Business and Psychology, Vol. 17 No. 2, pp. 245-260.

Du Preez, R., Bendixen, M. and Abratt, R. (2017), "The behavioral consequences of internal brand management among frontline employees", The fournal of Product $\mathcal{E}$ Brand Management, Vol. 26 No. 3, pp. 251-261.

Dubois, E., Gruzd, A. and Jacobson, J. (2020), "Journalists' use of social media to infer public opinion: the citizens' perspective", Social Science Computer Review, Vol. 38 No. 1, pp. 57-74.

Duncan, S.Y., Chohan, R. and Ferreira, J.J. (2019), "What makes the difference? Employee social media brand engagement", Fournal of Business \& Industrial Marketing, Vol. 34 No. 7, pp. 1459-1467.

Edvardsson, B., Tronvoll, B. and Gruber, T. (2011), "Expanding understanding of service exchange and value cocreation: a social construction approach", fournal of the Academy of Marketing Science, Vol. 39 No. 2, pp. 327-339.

Erkmen, E. (2018), "Managing your brand for employees: understanding the role of organizational processes in cultivating employee brand equity", Administrative Sciences, Vol. 8 No. 3, p. 52.

Erz, A., Marder, B. and Osadchaya, E. (2018), "Hashtags: motivational drivers, their use, and differences between influencers and followers", Computers in Human Behavior, Vol. 89, pp. 48-60.
Fishbein, M. and Ajzen, I. (1975), Belief, Attitude, Intention, and Behavior: An Introduction to Theory and Research, Addison-Wesley, Reading.

Foster, C., Punjaisri, K. and Cheng, R. (2010), "Exploring the relationship between corporate, internal and employer branding", Fournal of Product E Brand Management, Vol. 19 No. 6, pp. 401-409.

Fournier, S. (1998), "Consumers and their brands: developing relationship theory in consumer research", fournal of Consumer Research, Vol. 24 No. 4, pp. 343-353.

France, C., Merrilees, B. and Miller, D. (2015), "Customer brand co-creation: a conceptual model", Marketing Intelligence E Planning, Vol. 33 No. 6, pp. 848-864.

France, C., Grace, D., Merrilees, B. and Miller, D. (2018), "Customer brand co-creation behavior: conceptualization and empirical validation", Marketing Intelligence E Planning, Vol. 36 No. 3, pp. 334-348.

FTC (2017), “The FTC's endorsement guides: what people are asking", available at: www.ftc.gov/tips-advice/ business-center/guidance/ftcs-endorsement-guides-whatpeople-are-asking (accessed 25 October 2019).

Gelb, B.D. and Deva, R. (2014), "Employee contributions to brand equity”, California Management Review, Vol. 56 No. 2, pp. 95-112.

Gil-Saura, I., Ruiz-Molina, M.E., Michel, G. and CorralizaZapata, A. (2013), "'Retail brand equity: a model based on its dimensions and effects', the international review of retail", Distribution and Consumer Research, Vol. 23 No. 2, pp. 111-136.

Gill-Simmen, L., MacInnis, D.J., Eisingerich, A.B. and Whan Park, C. (2018), "Brand-self connections and brand prominence as drivers of employee brand attachment", AMS Review, Vol. 8 Nos 3/4, pp. 128-146.

Glanfield, K., Ackfeldt, A. and Melewar, T. (2018), "Corporate branding's influence on front-line employee and consumer value co-creation in UK household consumer markets", Fournal of General Management, Vol. 43 No. 2, pp. 63-69.

Golbeck, J., Robles, C., Edmondson, M. and Turner, K. (2011), "Predicting personality from twitter", Paper presented at the 2011 IEEE Third International Conference on Privacy, Security, Risk and Trust and 2011 IEEE Third International Conference on Social Computing, Boston, pp. 149-156.

Grewal, D., Roggeveen, A.L. and Nordfält, J. (2017), "The future of retailing", fournal of Retailing, Vol. 93 No. 1, pp. 1-6.

Gruzd, A., Jacobson, J. and Dubois, E. (2020), "Cybervetting and the public life of social media data", Social Media + Society, Vol. 6 No. 2, pp. 1-13.

Gummesson, E. (2008), Total Relationship Marketing, 3rd ed., Elsevier/Butterworth-Heinemann.

Gwet, K.L. (2014), "Handbook of inter-rater reliability", 4th ed., Advanced Analytics, LLC, Gaitherburg, MD.

Hair, J.F., Black, W.C., Babin, B.J. and Anderson, R.E. (2014), Multivariate Data Analysis, 7th ed., Pearson Education, NJ.

Hambrick, M.E. (2017), "Riding into the future: a financial examination of SoulCycle and the indoor cycling studio 
trend", Case Studies in Sport Management, Vol. 6 No. 1, pp. 86-94.

Hambrick, M.E. and Kang, S.J. (2015), "Pin it: exploring how professional sports organizations use pinterest as a communications and relationship-marketing tool", Communication E Sport, Vol. 3 No. 4, pp. 434-457.

Harris, P. (2007), "We the people: the importance of employees in the process of building customer experience", Fournal of Brand Management, Vol. 15 No. 2, pp. 102-114.

Harris, E. and Bardey, A.C. (2019), "Do Instagram profiles accurately portray personality? An investigation into idealized online self-presentation", Frontiers in Psychology, Vol. 10, p. 871.

Hatch, M.J. and Schultz, M. (2010), "Toward a theory of brand co-creation with implications for brand governance", Fournal of Brand Management, Vol. 17 No. 8, pp. 590-604.

Henkel, S., Tomczak, T. and Wentzel, D. (2007), "Bringing the brand to life: structural conditions of brand-consistent employee behavior", Marketing Review St. Gallen, Vol. 24 No. 1, pp. 13-16.

Holland, P., Cooper, B.K. and Hecker, R. (2016), "Use of social media at work: a new form of employee voice?", The International fournal of Human Resource Management, Vol. 27 No. 21, pp. 2621-2634.

Homburg, C., Jozić, D. and Kuehnl, C. (2017), “Customer experience management: toward implementing an evolving marketing concept", Fournal of the Academy of Marketing Science, Vol. 45 No. 3, pp. 377-401.

Homer, P.M. (2009), "Product placements", Fournal of Advertising, Vol. 38 No. 3, pp. 21-32.

Hughes, D.E. and Ahearne, M. (2010), "Energizing the reseller's sales force: the power of brand identification", Fournal of Marketing, Vol. 74 No. 4, pp. 81-96.

Ind, N., Iglesias, O. and Schultz, M. (2013), "Building brands together. Emergence and outcomes of co-creation", California Management Review, Vol. 55 No. 3, pp. 5-26.

Instagram (2020), "Verified badges", available at: https://help. instagram.com/854227311295302

Islam, T. and Tariq, J. (2018), "Learning organizational environment and extra-role behaviors: the mediating role of employee engagement", The fournal of Management Development, Vol. 37 No. 3, pp. 258-270.

Iyengar, R., Van den Bulte, C. and Valente, T.W. (2011), "Opinion leadership and social contagion in new product diffusion”, Marketing Science, Vol. 30 No. 2, pp. 195-212.

Jacobson, J. (2020), "You are a brand: social media managers' personal branding and 'the future audience"', fournal of Product \& Brand Management, Vol. 29 No. 6.

Jacobson, J. and Mascaro, C. (2016), "Movember: twitter conversations of a hairy social movement", Social Media + Society, Vol. 2 No. 2, pp. 1-12.

Jacobson, J., Gruzd, A. and Hernández-García, Á. (2020), "Social media marketing: who is watching the watchers?", Fournal of Retailing and Consumer Services, Vol. 53, pp. 1-12.

Kashive, N. and Tandon Khanna, V. (2017), "Building employee brand equity to influence organization attractiveness and firm performance", International fournal of Business and Management, Vol. 12 No. 2, pp. 207-219.
Kassing, J.W. (2002), “Speaking up: identifying employees' upward dissent strategies", Management Communication Quarterly, Vol. 16 No. 2, pp. 187-209.

Katz, D. (1964), "The motivational basis of organizational behavior", Behavioral Science, Vol. 9 No. 2, pp. 131-146.

Katz, E. and Lazarsfeld, P.F. (1955), Personal Influence, the Part Played by People in the Flow of Mass Communications, The Free Press.

Keller, K.L. (1993), "Conceptualizing, measuring, and managing customer-based brand equity", Fournal of Marketing, Vol. 57 No. 1, pp. 1-22.

Keller, K.L. and Lehmann, D.R. (2006), "Brands and branding: research findings and future priorities", Marketing Science, Vol. 25 No. 6, pp. 740-759.

King, C. (2017), "Brand management - standing out from the crowd: a review and research agenda for hospitality management", International fournal of Contemporary Hospitality Management, Vol. 29 No. 1, pp. 115-140.

King, C. and Grace, D. (2009), "Employee based brand equity: a third perspective", Services Marketing Quarterly, Vol. 30 No. 2, pp. 122-147.

King, C. and Grace, D. (2010), "Building and measuring employee-based brand equity", European Fournal of Marketing, Vol. 44 Nos 7/8, pp. 938-971.

King, C. and So, K.K.F. (2013), "Enhancing hotel employees' brand understanding and brand-building behavior in China", Fournal of Hospitality E Tourism Research, Vol. 39 No. 4, pp. 492-516.

King, C., Grace, D. and Funk, D.C. (2012), "Employee brand equity: scale development and validation", Fournal of Brand Management, Vol. 19 No. 4, pp. 268-288.

Kowalczyk, C.M. and Pounders, K.R. (2016), "Transforming celebrities through social media: the role of authenticity and emotional attachment", The fournal of Product \& Brand Management, Vol. 25 No. 4, pp. 345-356.

Kübler, R.V., Colicev, A. and Pauwels, K.H. (2020), "Social media's impact on the consumer mindset: when to use which sentiment extraction tool?", fournal of Interactive Marketing, Vol. 50, pp. 136-155.

Kumar, V. and Pansari, A. (2014), "The construct, measurement, and impact of employee engagement: a marketing perspective", Customer Needs and Solutions, Vol. 1 No. 1, pp. 52-67.

Lemon, K.N. and Verhoef, P.C. (2016), "Understanding customer experience throughout the customer journey", fournal of Marketing, Vol. 80 No. 6, pp. 69-96.

Lock, S. (2020), “Market size of the global wellness industry in 2015-2017, by segment", available at: www.statista.com/ statistics/270720/market-size-of-the-wellness-industry-bysegment/ (accessed 14 March 2020).

Locker, M. (2017), "SoulCycle is heading to London on its stationary bikes", available at: www.fastcompany.com/ 40496715/soulcycle-is-heading-to-london-on-its-stationarybikes (accessed 19 October 2019).

Lu, L., Chang, W. and Chang, H. (2014), "Consumer attitudes toward blogger's sponsored recommendations and purchase intention: the effect of sponsorship type, product type, and brand awareness", Computers in Human Behavior, Vol. 34, pp. 258-266. 
McColl-Kennedy, J.R., Vargo, S.L., Dagger, T.S., Sweeney, J. C. and van Kasteren, Y. (2012), "Health care customer value cocreation practice styles", fournal of Service Research, Vol. 15 No. 4, pp. 370-389.

Martin, G., Parry, E. and Flowers, P. (2015), "Do social media enhance constructive employee voice all of the time or just some of the time? Social media and employee voice", Human Resource Management fournal, Vol. 25 No. 4, pp. 541-562.

Maynard, M.T., Gilson, L.L. and Mathieu, J.E. (2012), "Empowerment - fad or fab? A multilevel review of the past two decades of research", fournal of Management, Vol. 38 No. 4, pp. 1231-1281.

Merrilees, B., Miller, D. and Yakimova, R. (2017), "The role of staff engagement in facilitating staff-led value cocreation", fournal of Service Management, Vol. 28 No. 2, pp. 250-264.

Mikic Little, M. and Dean, A.M. (2006), "'Links between service climate, employee commitment and employees' service quality capability', managing service quality", Managing Service Quality: An International fournal, Vol. 16 No. 5, pp. 460-476.

Miles, S.J. and Mangold, G. (2004), "A conceptualization of the employee branding process", Fournal of Relationship Marketing, Vol. 3 Nos 2/3, pp. 65-87.

Miles, S.J. and Mangold, G. (2014), "Employee voice: untapped resource or social media time bomb?", Business Horizons, Vol. 57 No. 3, pp. 401-411.

Miles, S.J. and Muuka, G.N. (2011), "Employee choice of voice: a new workplace dynamic", Fournal of Applied Business Research (FABR), Vol. 27 No. 4, pp. 91-104.

Miles, M.B., Huberman, A.M. and Saldaña, J. (2014), Qualitative Data Analysis: A Methods Sourcebook, 3rd ed., Sage, Thousand Oaks, CA.

Morhart, F.M., Herzog, W. and Tomczak, T. (2009), "Brandspecific leadership: turning employees into brand champions", Fournal of Marketing, Vol. 73 No. 5, pp. 122-142.

Moulard, J.G., Raggio, R.D. and Folse, J.A.G. (2016), "Brand authenticity: testing the antecedents and outcomes of brand management's passion for its products”, Psychology \& Marketing, Vol. 33 No. 6, pp. 421-436.

Neuendorf, K.A. (2017), The Content Analysis Handbook, 2nd ed., Sage, Thousand Oaks, CA.

Organ, D.W. (1988), Organizational Citizenship Behavior: The Good Soldier Syndrome, Lexington, Lexington, MA.

Ouellette, J.A. and Wood, W. (1998), "Habit and intention in everyday life: the multiple processes by which past behaviour predicts future behaviour", Psychological Bulletin, Vol. 124 No. 1, pp. 54-74.

Paine, J.B. and Organ, D.W. (2000), "The cultural matrix of organizational citizenship behavior: some preliminary conceptual and empirical observations", Human Resource Management Review, Vol. 10 No. 1, pp. 45-59.

Payne, A., Storbacka, K., Frow, P. and Knox, S. (2009), "Cocreating brands: diagnosing and designing the relationship experience", Fournal of Business Research, Vol. 62 No. 3, pp. 379-389.

Piehler, R., Grace, D. and Burmann, C. (2018), "Internal brand management: introduction to the special issue and directions for future research", Fournal of Brand Management, Vol. 25 No. 3, pp. 197-201.
Pitt, C.S., Plangger, K.A., Botha, E., Kietzmann, J. and Pitt, L. (2019), "How employees engage with B2B brands on social media: word choice and verbal tone", Industrial Marketing Management, Vol. 81, pp. 130-137.

Poulis, A. and Wisker, Z. (2016), "Modeling employee-based brand equity (EBBE) and perceived environmental uncertainty (PEU) on a firm's performance", The fournal of Product E Brand Management, Vol. 25 No. 5, pp. 490-503.

Punjaisri, K. and Wilson, A. (2011), "Internal branding process: key mechanisms, outcomes and moderating factors”, European Fournal of Marketing, Vol. 45 Nos 9/10, pp. 1521-1537.

Rafiq, M. and Ahmed, P.K. (2000), "Advances in the internal marketing concept: definition, synthesis and extension", Fournal of Services Marketing, Vol. 14 No. 6, pp. 449-462.

Raj Devasagayam, P., Buff, C.L., Aurand, T.W. and Judson, K. M. (2010), "Building brand community membership within organizations: a viable internal branding alternative?", fournal of Product E Brand Management, Vol. 19 No. 3, pp. 210-217.

Reade, J. (2020), "Keeping it raw on the 'gram: authenticity, relatability and digital intimacy in fitness cultures on Instagram"”, New Media \& Society, pp. 1-19.

Roncha, A. and Radclyffe-Thomas, N. (2016), "How TOMS' 'one day without shoes' campaign brings stakeholders together and co-creates value for the brand using Instagram as a platform", fournal of Fashion Marketing and Management, Vol. 20 No. 3, pp. 300-321.

Roth, R. (2019), "IBISWorld industry report 71394. Gym, health, \& fitness clubs in the US", IBISWorld Database, available at: www.ibisworld.com/united-states/marketresearch-reports/gym-health-fitness-clubs-industry/ (accessed 20 October 2019).

Russmann, U. and Svensson, J. (2016), "Studying organizations on Instagram”, Information, Vol. 7 No. 4, pp. 1-12.

Sadri, G. (2012), "Empowerment for the bottom line", Strategic Direction, Vol. 28 No. 2.

Saleem, F.Z. and Iglesias, O. (2016), "Mapping the domain of the fragmented field of internal branding", Fournal of Product E Brand Management, Vol. 25 No. 1, pp. 43-57.

Schade, J. (2008), "Creating brand ambassadors: how to help employees promote the brand", available at: www. jrsconsulting.net/pf_12.html (accessed 19 October 2019).

Schmidt, H.J. and Baumgarth, C. (2018), "Strengthening internal brand equity with brand ambassador programs: development and testing of a success factor model", fournal of Brand Management, Vol. 25 No. 3, pp. 250-265.

Sharma, G. (2017), "The explosion of influencer marketing over the past 24 months", available at: www.smartinsights. com/online-pr/influencer-marketing/explosion-influencermarketing-past-24-months/ (accessed 15 March 2020).

Shaver, P., Schwartz, J., Kirson, D. and O'Connor, C. (1987), "Emotion knowledge: further exploration of a prototype approach", Fournal of Personality and Social Psychology, Vol. 52 No. 6, pp. 1061-1086.

Sim, J., Saunders, B., Waterfield, J. and Kingstone, T. (2018), "Can sample size in qualitative research be determined a priori?", International fournal of Social Research Methodology, Vol. 21 No. 5, pp. 619-634. 
Singh, J., Crisafulli, B., Quamina, L.T. and Xue, M.T. (2020), "'To trust or not to trust': the impact of social media influencers on the reputation of corporate brands in crisis", Fournal of Business Research, Vol. 119, pp. 464-480.

Sirianni, N.J., Bitner, M.J., Brown, S.W. and Mandel, N. (2013), "Branded service encounters: strategically aligning employee behavior with the brand positioning", fournal of Marketing, Vol. 77 No. 6, pp. 108-123.

Softonic Solutions (Producer) (2018), " $4 \mathrm{k}$ stogram 2.1", available at: https://4k-stogram.en.softonic.com/ (accessed 13 August 2018).

Sonne, J. and Erickson, I. (2018), "The expression of emotions on Instagram", Proceedings of the 9th International Conference on Social Media E Society, Copenhagen, Denmark.

SoulCycle (2019), "Who we are", available at: www.soul-cycle. com/our-story/ (accessed 31 January 2020).

Spector, R. and McCarthy, P.D. (2000), The Nordstrom Way: The inside Story of America's \#1 Customer Service Company, 2nd ed., John Wiley \& Sons, New York, NY.

Spreitzer, G.M. (1995), "Psychological empowerment in the workplace: dimensions, measurement, and validation", The Academy of Management fournal, Vol. 38 No. 5, pp. 1442-1465.

Statista (2018), "Social content sharing", available at: www. statista.com/study/13181/user-generated-content-and-socialsharingstatista-dossier/ (accessed 18 May 2019).

Su, S., Wang, Y., Zhang, Z., Chang, C. and Zia, M.A. (2018), "Identifying and tracking topic-level influencers in the microblog streams", Machine Learning, Vol. 107 No. 3, pp. 551-578.

Tajfel, H. and Turner, J.C. (1986), "The social identity theory of intergroup behavior", in Worchel, S. and Austin, W.G. (Eds), Psychology of Intergroup Relations, Nelson-Hall, Chicago, pp. 7-24.

Thomson, K., de Chernatony, L., Arganbright, L. and Khan, S. (1999), "The buy-in benchmark: how staff understanding and commitment impact brand and business performance", Fournal of Marketing Management, Vol. 15 No. 8, pp. 819-835.

Tiggemann, M. and Zaccardo, M. (2018), "'Strong is the new skinny': a content analysis of \#fitspiration images on Instagram", Fournal of Health Psychology, Vol. 23 No. 8, pp. 1003-1011.

Tosti, D.T. and Stotz, R.D. (2001), "Brand: building your brand from the inside out", Marketing Management, Vol. 10 No. 2, pp. 28-33.
Trusov, M., Bodapati, A.V. and Bucklin, R.E. (2010), "Determining influential users in internet social networks", Fournal of Marketing Research, Vol. 47 No. 4, pp. 643-658.

Tschohl, J. (1998), "Empowerment - the key to quality service”, Managing Service Quality: An International fournal, Vol. 8 No. 6, pp. 421-425.

Tschohl, J. (2018), “6 Steps to invest in your people to develop a customer-driven workforce", available at: www.hr.com/en/ magazines/hcm_sales_marketing_alliance_excellence_essentials/ november_2018_hcm_sales_marketing_alliance/6-stepsto-invest-in-your-people-to-develop-a-cust_jogoeheo.html (accessed 15 October 2019).

Tuten, T.L. and Solomon, M.R. (2018), Social Media Marketing, Sage, New Delhi.

van de Mortel, T. (2008), "Faking it: social desirability response bias in self-report research", The Australian Fournal of Advanced Nursing, Vol. 25 No. 4, pp. 40-48.

Veloutsou, C. and Guzman, F. (2017), "The evolution of brand management thinking over the last 25 years as recorded in the journal of product and brand management", Fournal of Product E Brand Management, Vol. 26 No. 1, pp. 2-12.

Wangenheim, F., Evanschitzky, H. and Wunderlich, M. (2007), "Does the employee customer satisfaction link hold for all employee groups?", Fournal of Business Research, Vol. 60 No. 7, pp. 690-697.

Watts, D. and Dodds, P. (2007), "Influentials, networks, and public opinion formation", fournal of Consumer Research, Vol. 34 No. 4, pp. 441-458.

Wee, L. and Brooks, A. (2010), "Personal branding and the commodification of reflexivity", Cultural Sociology, Vol. 4 No. 1, pp. 45-62.

Yi, Y. and Gong, T. (2013), "Customer value co-creation behavior: scale development and validation", fournal of Business Research, Vol. 66 No. 9, pp. 1279-1284.

Yin, R.K. and Campbell, D.T. (2018), Case Study Research and Applications: Design and Methods, 6th ed., Sage.

Yoo, B. and Donthu, N. (2001), "Developing and validating a multidimensional consumer-based brand equity scale", Fournal of Business Research, Vol. 52 No. 1, pp. 1-14. 


\section{Appendix. Summary of the codebook with examples}

\begin{tabular}{|c|c|c|}
\hline \multicolumn{3}{|l|}{ Brand consistent behavior } \\
\hline Item description & Soulcycle application & Example \\
\hline $\begin{array}{l}\text { 1. Image content: } \\
\text { Image aligns with the } \\
\text { organization's brand values }\end{array}$ & $\begin{array}{l}\text { Image is fitness-related } \\
\text { posing and fitness-related } \\
\text { activities }\end{array}$ & -2 \\
\hline $\begin{array}{l}\text { 2. Image emotion: } \\
\text { Image showcases emotions } \\
\text { that are aligned with brand } \\
\text { consistent behaviors }\end{array}$ & $\begin{array}{l}\text { Image showcases emotions } \\
\text { including happiness, hard } \\
\text { work, humor, or } \\
\text { thoughtfulness }\end{array}$ & \\
\hline $\begin{array}{l}\text { 3. Image setting: } \\
\text { Image is taken at the } \\
\text { organization }\end{array}$ & $\begin{array}{l}\text { Image is taken at the interior } \\
\text { or exterior of a SoulCycle } \\
\text { studio }\end{array}$ & 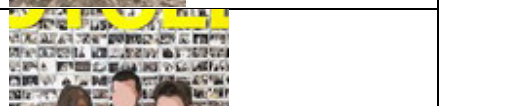 \\
\hline $\begin{array}{l}\text { 4. Caption emotion: } \\
\text { Caption's emotion is aligned } \\
\text { with the organization's brand } \\
\text { values }\end{array}$ & $\begin{array}{l}\text { The caption's emotion is } \\
\text { happiness, excitement, } \\
\text { satisfaction, pride, wisdom, } \\
\text { gratitude, love, } \\
\text { informational, request, } \\
\text { welcoming, anticipation, } \\
\text { surprise, humor, overcoming } \\
\text { obstacles, or hard work }\end{array}$ & $\begin{array}{l}\text { Never forget that you can do difficult things } \\
\text { \#soulcycle \#soulstyle }\end{array}$ \\
\hline $\begin{array}{l}\text { 5. Caption brand values: } \\
\text { Caption is aligned with the } \\
\text { organization's brand values }\end{array}$ & $\begin{array}{l}\text { Caption is health and/or } \\
\text { fitness related }\end{array}$ & $\begin{array}{l}\text { Doing pilates has taught me so much. } \\
\text { Today l'm remembering to take things slow } \\
\text { and do things right. Society is so fast paced, } \\
\text { but we need to remember to slow, think, and } \\
\text { appreciate. My teacher training with @brand } \\
\text { comes to an end, I am learning the } \\
\text { importance of listening to your body. Let's } \\
\text { make the absolute most out of this life. }\end{array}$ \\
\hline \multicolumn{3}{|l|}{ Brand endorsement } \\
\hline Item description & Soulcycle application & Example \\
\hline $\begin{array}{l}\text { 1. Image branding: } \\
\text { Image showcases employer- } \\
\text { branded merchandise }\end{array}$ & $\begin{array}{l}\text { Image showcases } \\
\text { Soulcycle-branded } \\
\text { merchandise }\end{array}$ & \\
\hline $\begin{array}{l}\text { 2. Caption branding: } \\
\text { Caption explicitly mentions } \\
\text { the employer in the post }\end{array}$ & $\begin{array}{l}\text { Caption explicitly mentions } \\
\text { SoulCycle in the post }\end{array}$ & $\begin{array}{l}\text { Spending weekends outside the city have healed and } \\
\text { grounded me. Between teaching @soulcycle in studios } \\
\text { in the suburbs, doing yoga at my parent's backyard, } \\
\text { napping in the sunshine, and taking long walks at the } \\
\text { beach, I'm at peace with this slower pace. Getting up } \\
\text { and eating early by the water are keeping me deeply } \\
\text { centred. I'm incredibly thankful for my summer } \\
\text { weekends rn. } \\
\text { On Sundays, I prepare for the week ahead. There's a } \\
\text { small shift in the schedule and a special cameo at our } \\
\text { studio (YES you guys), I've got a week full of yoga, early } \\
\text { nights, and home-made meals. } \\
\text { \#itsgonnabeagreatweek } \\
\text { \#soulcycle } \\
\text { \#Sunday }\end{array}$ \\
\hline $\begin{array}{l}\text { 3. Hashtag branding: } \\
\text { Caption includes an } \\
\text { employer-branded hashtag }\end{array}$ & $\begin{array}{l}\text { Caption includes a } \\
\text { SoulCycle-related hashtag }\end{array}$ & $\begin{array}{l}\text { In case you can't see, I'm just over here dying after my } \\
\text { @soulcycle class. But in the best possible way. } \\
\text { \#soulgifted \#soulcycle }\end{array}$ \\
\hline $\begin{array}{l}\text { 4. Call to action: } \\
\text { Caption includes an offer or } \\
\text { demand that directly speaks } \\
\text { to the audience compelling } \\
\text { them to act }\end{array}$ & $\begin{array}{l}\text { Caption includes a } \\
\text { SoulCycle-related call to } \\
\text { action }\end{array}$ & $\begin{array}{l}\text { It's Thursday! And you know that means HIPHOP class!! } \\
\text { See you tonight! }\end{array}$ \\
\hline
\end{tabular}




\begin{tabular}{|c|c|c|}
\hline \multicolumn{3}{|l|}{ Brand allegiance } \\
\hline Item description & Soulcycle application & Example \\
\hline $\begin{array}{l}\text { 1. Bio branding: } \\
\text { Bio includes the employer in } \\
\text { the hashtag, tagged } \\
\text { username, or any other } \\
\text { mention of the brand }\end{array}$ & $\begin{array}{l}\text { Instagram bio includes } \\
\text { SoulCycle }\end{array}$ & $\begin{array}{l}\text { First name Last name @soulcycle instructor ClassPass } \\
\text { Best Instructor personal trainer. Location } \\
\text { \#TheLastnameExperience } \\
\text { www.soul-cycle.com/instructors/lastname }\end{array}$ \\
\hline $\begin{array}{l}\text { 2. Bio position branding: } \\
\text { Bio includes whether the } \\
\text { employee is a more senior, } \\
\text { higher level employee within } \\
\text { the organization }\end{array}$ & $\begin{array}{l}\text { Instagram bio includes the } \\
\text { employee's rank as master } \\
\text { or senior Soulcycle } \\
\text { instructor }\end{array}$ & $\begin{array}{l}\text { First name Lastname Author of Book, Contributor to } \\
\text { website.com; SOULCYCLE Senior Master Instructor; } \\
\text { Follow my book @bookhandle } \\
\text { bookwebsite.com } \\
\text { Instagram handle }\end{array}$ \\
\hline $\begin{array}{l}\text { 3. Profile branding: } \\
\text { Profile photo shows the } \\
\text { employee is wearing or } \\
\text { using any company branded } \\
\text { merchandise or displaying } \\
\text { their company logo }\end{array}$ & $\begin{array}{l}\text { Profile photo shows } \\
\text { employee wearing } \\
\text { SoulCycle-branded } \\
\text { merchandise or displaying } \\
\text { Soulcycle logo }\end{array}$ & \\
\hline $\begin{array}{l}\text { 4. Profile location } \\
\text { branding: } \\
\text { Profile photo includes the } \\
\text { company or company logo is } \\
\text { visible in the background }\end{array}$ & $\begin{array}{l}\text { Profile photo includes the } \\
\text { SoulCycle studio or logo in } \\
\text { the background }\end{array}$ & . \\
\hline
\end{tabular}

\section{About the authors}

Donna Smith is a Professor at Ryerson University's Ted Rogers School of Retail Management, Toronto, Canada. Her research interests focus on influencer and celebrity-endorsed retail social media campaigns and an examination of multi-sided social media platform partnerships.

Jenna Jacobson is an Assistant Professor at Ryerson University's Ted Rogers School of Retail Management. She is also a Research Fellow at Ryerson's Social Media Lab. Her research analyzes the consumer and producer perspectives of digital technologies with a focus on social media, branding, digital retailing and user behavior. Jenna Jacobson is the corresponding author and can be contacted at: jenna. jacobson@ryerson.ca

Janice L. Rudkowski is an Assistant Professor at Ryerson University's Ted Rogers School of Retail Management in Toronto, Canada. Her main research interests lie within the employee brand equity, customer journey and experience and category management areas, with a focus on retail.

For instructions on how to order reprints of this article, please visit our website:

www.emeraldgrouppublishing.com/licensing/reprints.htm

Or contact us for further details: permissions@emeraldinsight.com 